\title{
Corrosion Behavior of Titanate Ceramics in Short-term MCC-1 Tests: The Effects of Surface Finish
}

\author{
A.J. Bakel, J.K. Basco, M.K. Nole and D.B. Chamberlain
}

June 1, 2000

U.S. Department of Energy

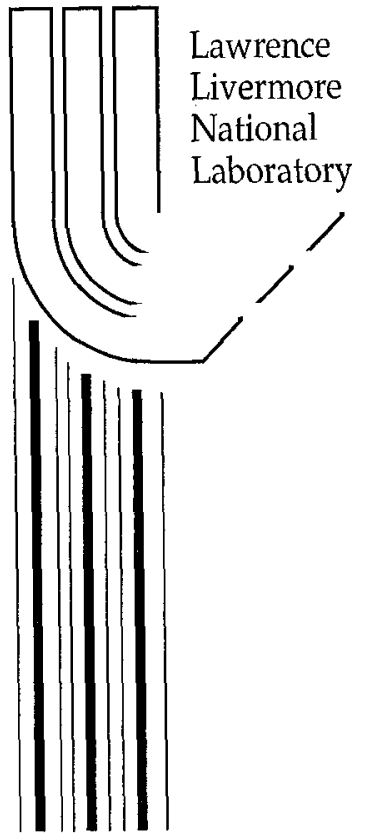




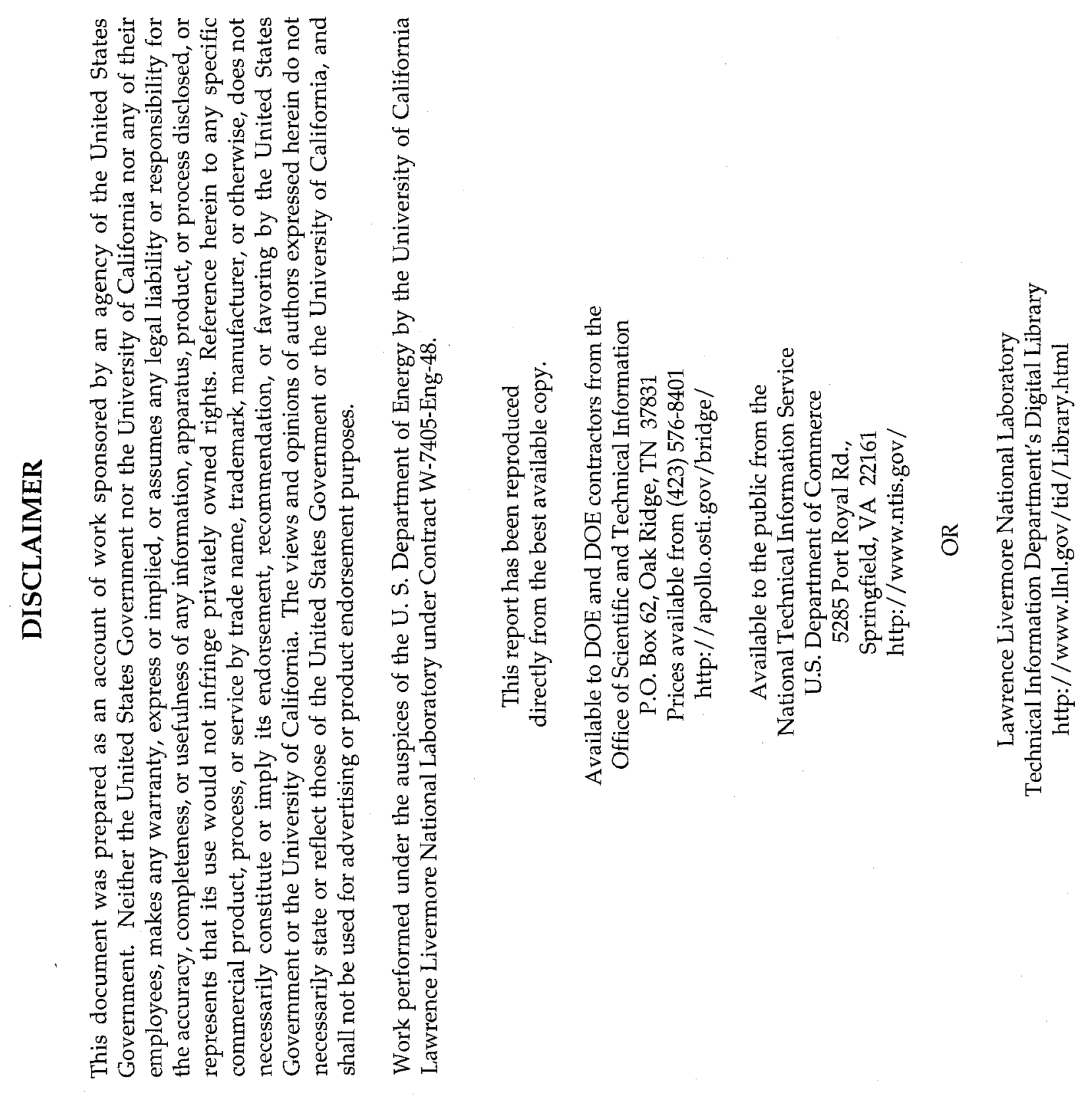




\title{
ANL-00/14
}

Argonne National Laboratory

Chemical Technology Division

9700 South Cass Avenue

Argonne, IL 60439

\section{CORROSION BEHAVIOR OF TITANATE CERAMICS IN SHORT-TERM MCC-1. TESTS: THE EFFECTS OF SURFACE FINISH}

by

\begin{abstract}
Allen J. Bakel, John K. Basco, Michael K. Nole, and David B. Chamberlain
Chemical Technology Division
\end{abstract}

Sponsor Report

June 2000

* This work was performed under guidance of the DOS Fissile Materials Disposition Program (FMD). Work supported by the U.S. Department of Energy under contract W-31-109-ENG-38. 
This page left blank intentionally. 


\section{TABLE OF CONTENTS}

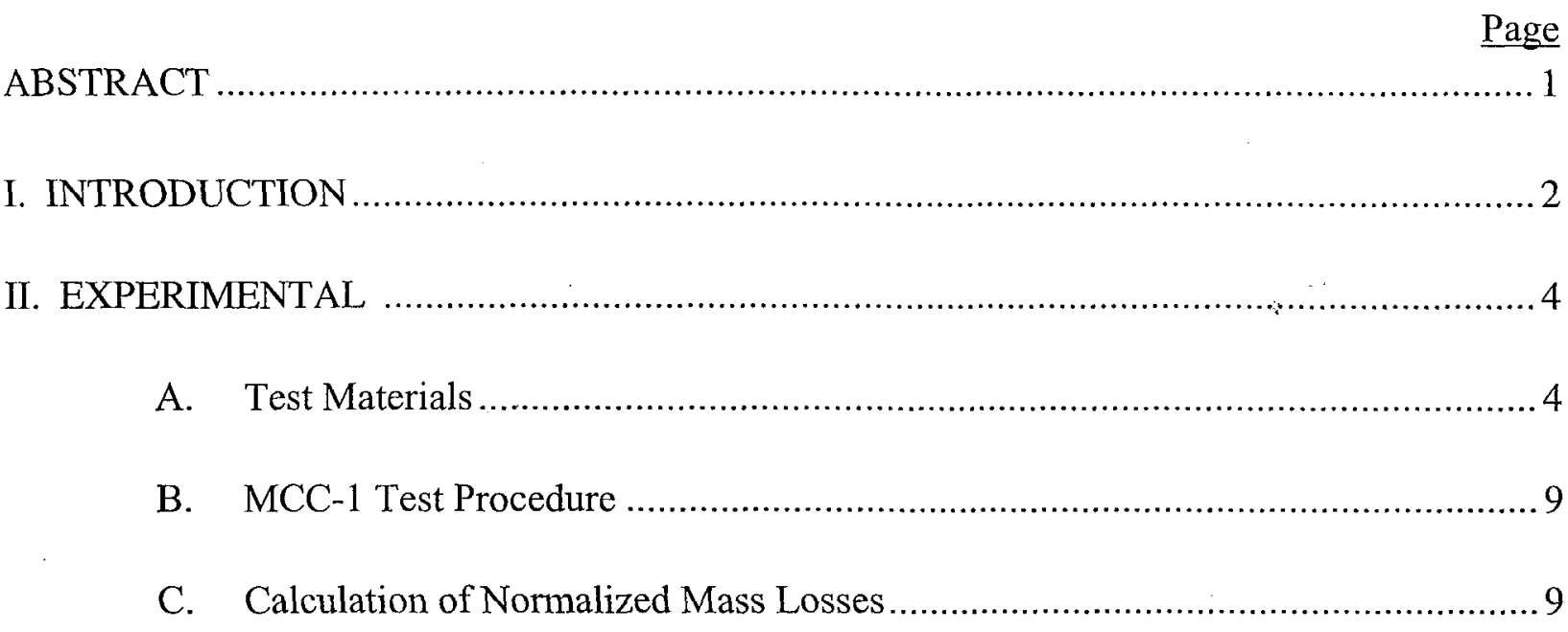

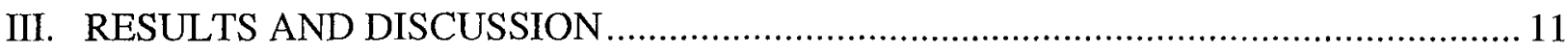

A. Blank Test Concentrations .......................................................................... 11

B. Tests with Hf-Ce-Ce Ceramic .................................................................... 12

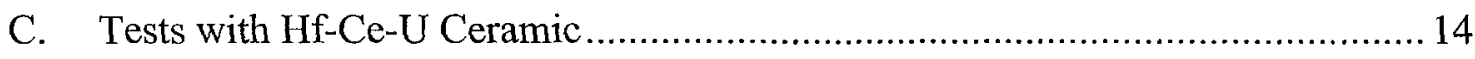

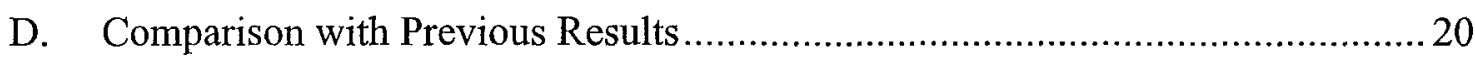

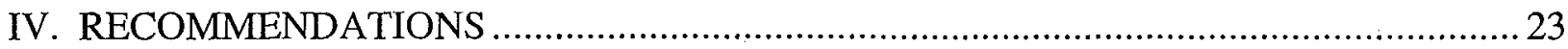

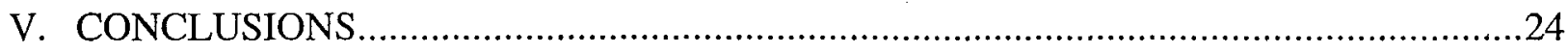

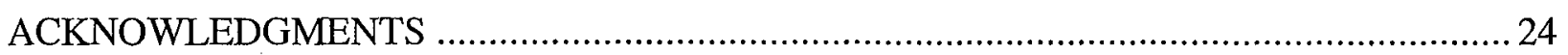

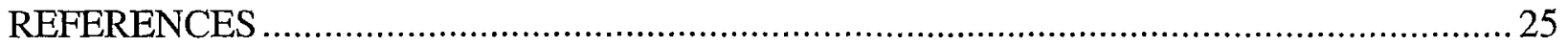

APPENDIX A. PROCEDURE FOR CLEANING NEW TEFLON ${ }^{\circledast}$ TEST VESSELS/ PROCEDURE FOR CLEANING USED TEFLON ${ }^{\circledR}$ TEST VESSELS ...................................2 27

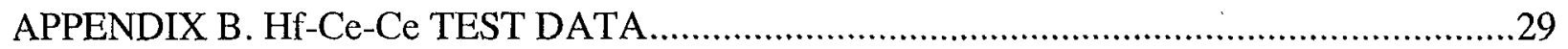

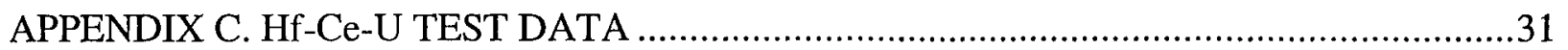




\section{LIST OF FIGURES}

No.

Title

Page

1A. SEM Micrograph (backscattered electron) of an Unreacted, Polished (1200-grit SiC paper) surface of the Hf-Ce-Ce Ceramic. Phase identifications are made on the basis of contrast, and qualitative EDS analysis

1B. SEM Micrograph (backscattered electron) of an Unreacted, Polished (1200-grit SiC paper) surface of the $\mathrm{Hr}-\mathrm{Ce}-\mathrm{U}$ Ceramic. Phase Identifications are made on the basis of contrast, and qualitative EDS analysis

1C. TEM images of the Hf-Ce-Ce Ceramic. Samples prepared by tripod thinning and ion milling. There is evidence of intergrowth structures of zirconolite polytypes within the main pyochlore phase.

2A. SEM Micrograph (backscattered electron) of an Unreacted Surface of the Hf-Ce-U Ceramic, Finished to 240-grit. 8

2B. SEM Micrograph (backscattered electron) of an Unreacted Surface of the Hf-Ce-U Ceramics, Finished to 600 -grit 8

3. Plot of the Average Normalized Mass Loss Values from Tests with the Hf-Ce-Ce Ceramics at two Different Surface Finishes. The Error Bars Represent the Standard Deviations. Note the Different Scales for Different Elements. Data are Listed in Table 3.

4A. Plot of Average NL(Ca) Values as a Function of Reaction Time in MCC-1 Tests with the Hf-Ce-U Ceramic. The Error Bars Represent the Standard Deviations.

4B. Plot of Average NL(Ca) Values as a Function of Reaction Time in MCC-1 Tests with the Hf-Ce-U Ceramic. The Error Bars Represent the Standard Deviations.

4C. Plot of Average NL(Ce) Values as a Function of Reaction Time in MCC-1 Tests with the Hf-Ce-U Ceramic. The Error Bars Represent the Standard Deviations.

4D. Plot of Average NL(U) Values as a Function of Reaction Time in MCC-1 Tests with the Hf-Ce-U Ceramic. The Error Bars Represent the Standard Deviations. 


\section{LIST OF TABLES}

№.

1. Compositions of Ceramics Used in this Study 4

2. Averaged Concentrations, from Blank Tests in Stainless Steel and Teflon ${ }^{\circledR}$ .12

3. Results of Three-Day, $90^{\circ} \mathrm{C}$ MCC-1 Tests at Several Durations in DIW with a Hf-Ce-Ce Titanate Ceramic at Two Different Surface Finishes $\left(\mathrm{g} / \mathrm{m}^{2}\right)$

4. Results of 600 -Grit, $90^{\circ} \mathrm{C}$ MCC-1 Tests at Several Durations in DIW with a Hr-Ce-U Titanate Ceramic $\left(\mathrm{g} / \mathrm{m}^{2}\right)$

5. Results of 240 -Grit, $90^{\circ} \mathrm{C}$ MCC-1 Tests at Several Durations in DIW with a $\mathrm{Hr}-\mathrm{Ce}-\mathrm{U}$ titanate Ceramics $\left(\mathrm{g} / \mathrm{m}^{2}\right)$

6. Results from Three-Day MCC-1 Tests with Various Titanate Ceramics 20

7. Results from Three-Day MCC-1 Tests with Various Titanate Ceramics. Normalized Mass Loss Values Have Been Converted to Units of $\mathrm{g}$ Ceramic $/ \mathrm{m}^{2}$ 21

B-1. Test Information from Three-Day MCC-1 Tests With the Hf-Ce-Ce Ceramics. Uncertainties for the Monolith Measurements are Estimated as About 10\%. (Uncertainties for the Mass Measurements are $<1 \%$ ).

B-2. Concentrations, in ppb, in Leachates and Acid Strip Solutions from Blank MCC-1 Tests Run in Conjunction With the Hf-Ce-Ce Ceramics Tests. (Analytical Uncertainties are About 15\%) .29

B-3. Total (Uncorrected) Concentrations, in ppb, in Leachates and Acid Strip Solutions from Three-Day MCC-1 Tests with the Hf-Ce-Ce Ceramic. (Three Tests were Conducted with 240-Grit Finish and Three-Day Tests were Conducted with 600-Grit Finish. Analytical Uncertainties are about $15 \%$. 


\section{LIST OF TABLES (CONTD)}

No.

B-4. Background Corrected Concentrations, in ppb, in Leachates and Acid Strip Solutions from Three-Day MCC-1 Tests with the Hf-Ce-Ce Ceramic. (Three Tests were Conducted with 240-Grit Finish and Three-Day Tests were Conducted with 600-Grit Finish. Analytical Uncertainties are about $21 \%$ ) .30

C-1. Test Information from MCC-1 Tests with the Hf-Ce-U Ceramic. (Uncertainties for the Monolith Measurements are Estimated as about 10\%. Uncertainties for the Mass Measurements are $<1 \%$.) 31

C-2. Total Concentrations, in ppb, in Leachates and Acid Strip Solutions from Blank MCC-1 Tests Conducted in Conjunction with the Hf-Ce-U Ceramic Tests. (Analytical Uncertainties are about $15 \%$ )

C-3. Total (Uncorrected) Concentrations, in ppb, in Leachates and Acid Strip Solutions from MCC-1 Tests with Hf-Ce-U Ceramic. (Three Tests were Conducted with 240-Grit Finish and Three Tests were Conducted with 600-Grit Finish.

Analytic Uncertainties are 15\%). .33

C-4. Background Corrected Concentrations, in ppb, in Leachates and Acid Strip Solutions from MCC-1 Tests with the Hf-Ce-U Ceramic. (Three Tests were Conducted with 240-Grit Finish and Three Tests were Conducted with 600-Grit Finish. Analytical Uncertainties are about $21 \%$ 


\title{
CORROSION BEHAVIOR OF TITANATE CERAMICS IN SHORT-TERM MCC-1 TESTS: THE EFFECTS OF SURFACE FINISH
}

\author{
by
}

Allen J. Bakel, John K. Basco, Michael K. Nole and David B. Chamberlain

\begin{abstract}
Two series of MCC-1 tests were designed and conducted to describe the effects of surface finish on the corrosion behavior of titanate ceramics. These effects are important for the comparison of short-term test results from different laboratories. Test samples were prepared with 240 - and 600 -grit finishes. Tests, conducted for $1,3,7$, and 14 days at $90^{\circ} \mathrm{C}$, were carried out in Teflon ${ }^{\circledast}$ vessels. Two different ceramics were used in this study: a Hf-Ce-Ce ceramic containing pyrochlore, perovskite, rutile and a small amount of a silicate phase, and a Hf-Ce-U ceramic containing pyrochlore and rutile.

This study shows no detectable difference in the results of tests with ceramics finished to 240-grit and 600-grit; therefore, tests conducted at these two surface finishes can be directly compared. Due to its broader use, we recommend that short-term tests be conducted with monoliths finished to 600-grit. Comparison of data from blank tests in Teflon ${ }^{\circledR}$ and stainless steel vessels shows that the background associated with Teflon ${ }^{\oplus}$ vessels is lower. Therefore, we recommend that short-term tests be conducted in Teflon ${ }^{\circledR}$ vessels.
\end{abstract}




\section{INTRODUCTION}

\section{A. Background}

The dismantling of nuclear weapons and the cleanup of weapons production sites has generated large quantities of surplus weapons-grade plutonium $(\mathrm{Pu})$, contaminated $\mathrm{Pu}$ stock, and $\mathrm{Pu}$ scrap in the United States. The U.S. Department of Energy (DOE) has selected two options for the disposition of surplus $\mathrm{Pu}$. Some of the $\mathrm{Pu}$ will be incorporated into a mixed oxide fuel (MOX) for use in commercial reactors. The remaining $\mathrm{Pu}$ will be immobilized and disposed of in a stable titanate ceramic material. The titanate ceramics described and tested in this study represent the currently preferred pyrochlore-rich formulation; neither of these ceramics contains $\mathrm{Pu}$.

\section{B. Purpose}

Short-term tests have been conducted at Argonne National Laboratory (ANL) [BAKEL-1999c], Pacific Northwest National Laboratory (PNNL), Westinghouse Savannah River Company (WSRC) [CRAWFORD-1999], and Australian Nuclear Science and Technology Organization (ANSTO) [SMITH-1997] for the Fissile Materials Disposition (FMD) program. The tests at ANL were conducted with a 240-grit sample surface finish. The 240 -grit finish was chosen as the best practical alternative to the as-cut specification in the American Society for Testing and Materials (ASTM) procedure [ASTM-1998]. The procedure requires a laborintensive, time-consuming cutting process that uses a 220 -grit slow-speed saw blade, thus producing a 220-grit finish. We judged that finishing each monolith to 240-grit with SiC paper was quicker and more reproducible than the ASTM cutting procedure. In addition, many of our ceramic samples are fabricated as single monoliths, and do not require cutting [HASH-1999]; these samples can not be cut as described in the ASTM procedure.

Tests at PNNL and SRTC were conducted with ceramics having a 600-grit sample surface finish. In the case of radiation-damaged ceramics, a 600-grit finish was required to produce a consistent damaged layer [CRAWFORD-1999]. Therefore, in order to compare the test results from the different laboratories, it is important to understand the effects of the different sample surface treatments on the results of short-term MCC-1 tests. Previous studies demonstrated small but significant differences in the short-term corrosion behavior of glass monoliths, depending on surface finish [OH-1991, DUSSOSSOY-1992]. The primary purpose of this report is to document two series of tests designed to describe the effects of surface finish (240- vs. 600-grit) on the corrosion of titanate ceramics. 
A secondary purpose of this report is to document the use of Teflon ${ }^{\circledR}$ vessels in shortterm tests. Previous short-term corrosion studies have utilized 304L stainless steel test vessels [BAKEL-1999a, -1999b, -1999c]. Difficulties observed while using stainless steel vessels include problems with cleaning used vessels contaminated with $\mathrm{U}$ and $\mathrm{Pu}$, plus high background concentrations of Ca [BAKEL-1999c]. These difficulties led us to investigate the use of Teflon ${ }^{\circledR}$ vessels in the short-term tests described in this report. The advantages and disadvantages of Teflon $^{\circledast}$ vessels relative to stainless steel vessels are discussed in this report. 


\section{EXPERIMENTAL}

\section{A. Test Materials}

1. Fabrication Procedure

The titanate ceramics investigated for the tests described in this report were fabricated at ANL from chemicals in the proportions shown in Table 1. The precursor chemicals were wet ball-milled for 12 hours to grind and mix them. The mixture was calcined at $750^{\circ} \mathrm{C}$ for one hour. The calcined material was broken up by pushing it through a 20 -mesh sieve. The resulting powder was pressed into a $1.25 \mathrm{~cm}$ pellet by using a hydraulic press at about 700 $\mathrm{Kg} / \mathrm{cm}^{2}$, then sintered in air at $1350^{\circ} \mathrm{C}$ for four hours. The ceramic samples used in this study were fabricated as individual monoliths each about $1 \mathrm{~cm}$ in diameter and 2-3 $\mathrm{mm}$ thick.

Table 1. Compositions of ceramics used in this study

\begin{tabular}{|c|c|c|}
\hline Compound & Hf-Ce-Ce ${ }^{1}$ wt \%) & Hf-Ce-U ${ }^{2}(w t \%)$ \\
\hline $\mathrm{Ca}(\mathrm{OH})_{2}$ & 14.6 & 13.3 \\
$\mathrm{CeO}_{2}$ & 25.1 & 7.6 \\
$\mathrm{Gd}_{2} \mathrm{O}_{3}$ & 8.8 & 8.0 \\
$\mathrm{TiO}_{2}$ & 39.7 & 36.3 \\
$\mathrm{HfO}_{2}$ & 11.8 & 10.8 \\
$\mathrm{UO}_{2}$ & - & 24.0 \\
\hline Total $_{\text {Density }}^{2}$ & 100.0 & 100.0 \\
\hline
\end{tabular}

${ }^{1}$ These ceramic compositions are based on batch compositions; uncertainties are estimated at $10 \%$.

${ }^{2}$ Densities were determined geometrically; uncertainties are estimated at $10 \%$.

\section{Phase Composition}

Figure 1 shows electron micrographs of polished cross sections of the two ceramics used in this study. The areas shown in Figure 1a and $\mathrm{b}$ are small (about $100 \mu \mathrm{m} \times 75$ $\mu \mathrm{m})$, but they are judged to be representative of grain size and phase assemblage, but they may not be representative of porosity and minor phase distribution. These samples were prepared for SEM examination by sequentially polishing a monolith with 240-, 400-, 600-, and 1200-grit SiC paper. The grain size for the Hf-Ce-Ce ceramic is $10-40 \mu \mathrm{m}$, while the grain size for the Hf-Ce-U ceramic is $<10 \mu \mathrm{m}$. Figure 1c shows a transmission electron image of pyrochlore within the $\mathrm{Hf}-\mathrm{Ce}-\mathrm{Ce}$ ceramic. 
The Hf-Ce-Ce ceramic is composed of pyrochlore, rutile, perovskite, and a trace of a silicate phase. The pyrochlore contains $\mathrm{Ca}, \mathrm{Ti}, \mathrm{Hf}, \mathrm{Ce}$ and $\mathrm{Gd}$; the rutile contains $\mathrm{Ti}$ and $\mathrm{Hf}$; the perovskite contains $\mathrm{Ca}, \mathrm{Ti}$, and $\mathrm{Ce}$; and the silicate phase contains $\mathrm{Al}, \mathrm{Si}, \mathrm{P}, \mathrm{Ca}, \mathrm{Ti}, \mathrm{Ce}$, and $\mathrm{Gd}$. The $\mathrm{Si}, \mathrm{Al}$, and $\mathrm{P}$ were probably introduced as trace impurities in the batch chemicals. The phase compositions were determined by using qualitative EDS. The approximate phase assemblages in the area shown in Figure 1a are 50\% pyrochlore, 30\% perovskite, $10 \%$ rutile, $<1$ $\%$ silicate, and $<5 \%$ porosity. The baseline $\mathrm{Hf}-\mathrm{Ce}-\mathrm{U}$ ceramic is composed primarily of pyrochlore (containing $\mathrm{Ca}, \mathrm{Ti}, \mathrm{Hf}, \mathrm{Ce}, \mathrm{Gd}$, and $\mathrm{U}$ ) and rutile (containing $\mathrm{Ti}$ and $\mathrm{Hf}$ ). The approximate phase assemblage of the area shown in Figure $1 \mathrm{~b}$ is $80 \%$ pyrochlore, $15 \%$ rutile, and $<5 \%$ porosity. In both cases, the phase abundances were determined by digitizing the SEM images at a resolution of 1280 by 960 pixels (72 pixels/inch), defining a range of contrast/brightness for each phase, and calculating the area occupied by pixels having the specified ranges of contrast and brightness.

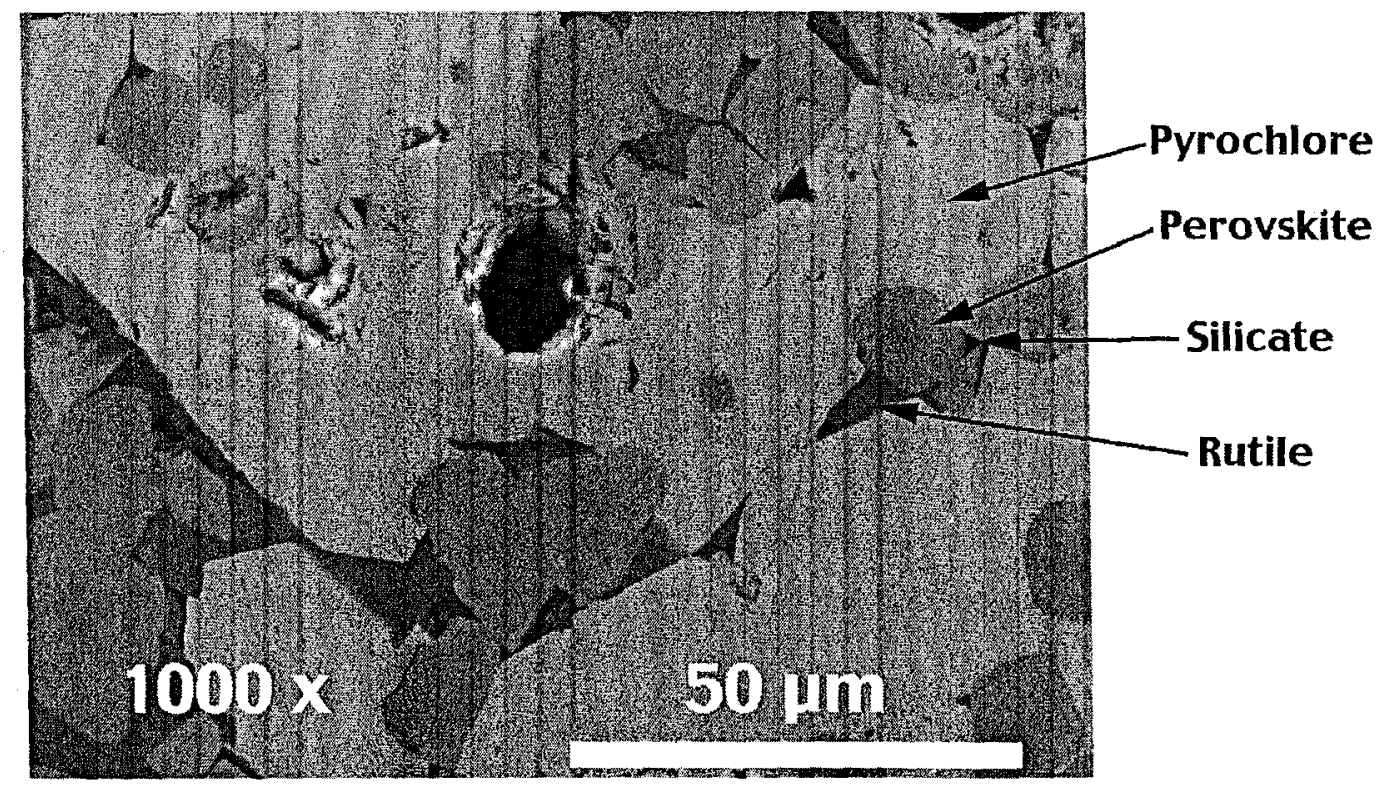

Figure 1a. SEM micrograph (backscattered electron) of an unreacted, polished (1200-grit SiC paper) surface of the Hf-Ce-Ce ceramic. Phase identifications are made on the basis of contrast, and qualitative EDS analysis. 


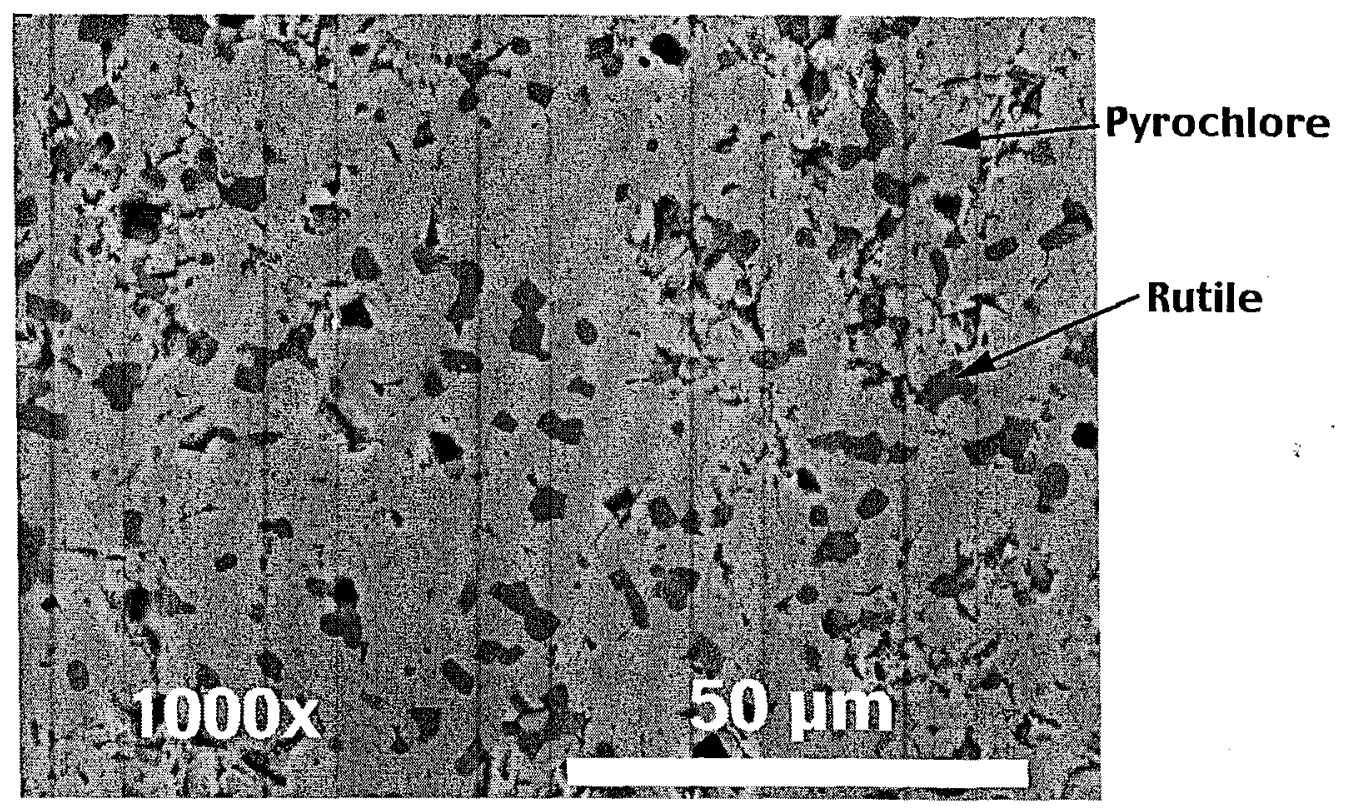

Figure 1b. SEM micrograph (backscattered electron) of an unreacted, polished (1200-grit SiC paper) surface of the Hf-Ce-U ceramic. Phase identifications are made on the basis of contrast, and qualitative EDS analyses.
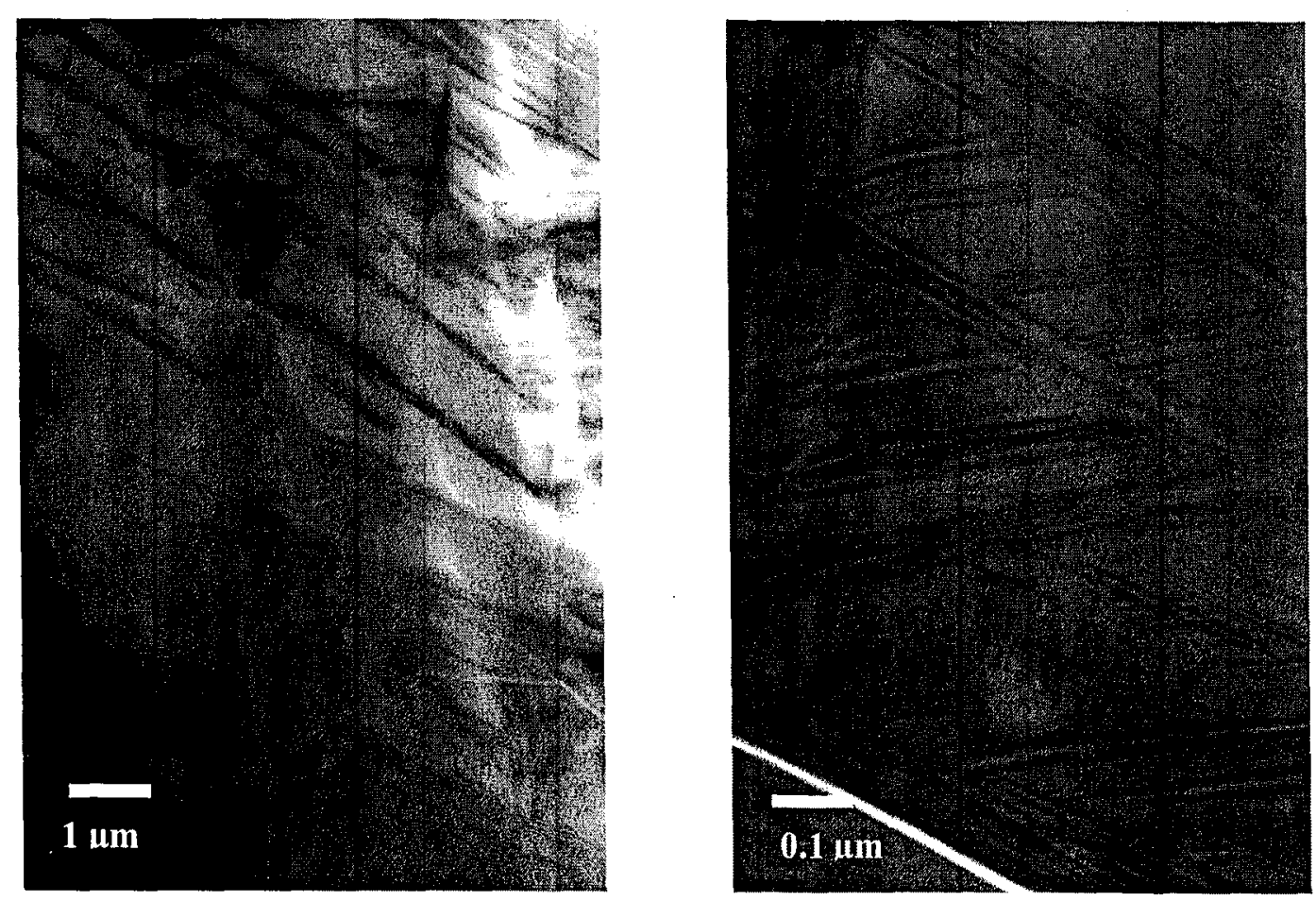

Figure 1c. TEM images of the Hf-Ce-Ce ceramic. Samples prepared by tripod thinning and ion milling. There is evidence of intergrowth structures of zirconolite polytypes within the main pyochlore phase. 


\section{Surface Finish}

After sintering, the ceramic samples (fabricated as monoliths, $1 \mathrm{~cm}$ in diameter and 2-3 mm thick) were polished to a 240 -grit finish, and then to a 600 -grit finish with wet $\mathrm{SiC}$ paper. Each monolith was visually inspected. Some of the samples were rejected because of such surface irregularities as chips or large voids. One half of the wafers were then refinished to 240-grit. Each wafer was ultrasonically cleaned in demineralized water (DIW) and ethanol. After cleaning, each monolith was again inspected to ensure a consistent surface finish. The geometric surface area of each monolith was calculated from its measured diameter and thickness. The uncertainty of these measurements is less than $10 \%$. Because of the actual surface area is higher than the geometric surface area by an unknown amount. Because of pores and surface roughness. Examples of a 40-grit and a 600-grit surface finish are shown in Figs. 2a and $2 b$. 


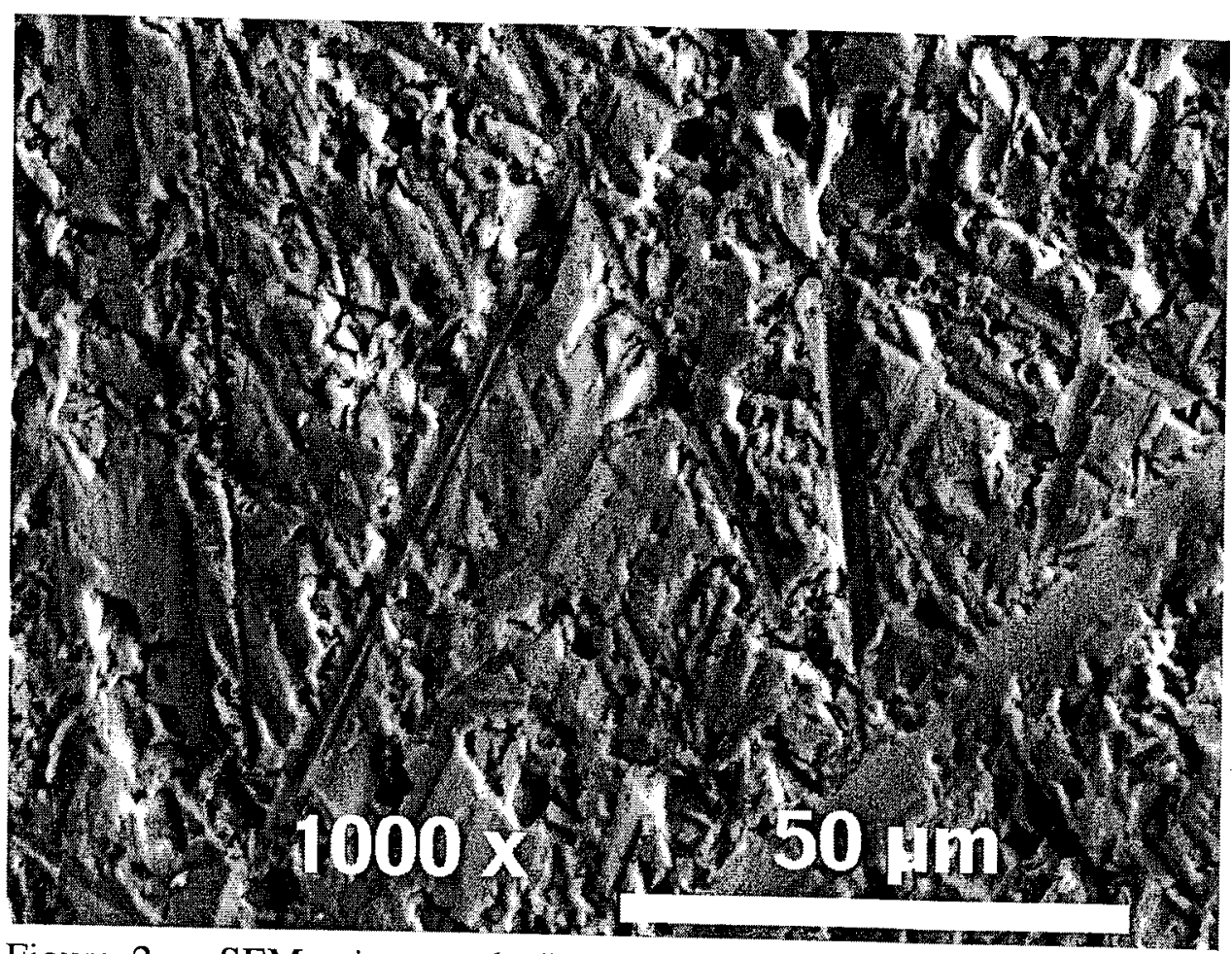

Figure 2a. SEM micrograph (backscattered electron) of an unreacted surface of the Hf-Ce-U ceramic, finished to 240 -grit.

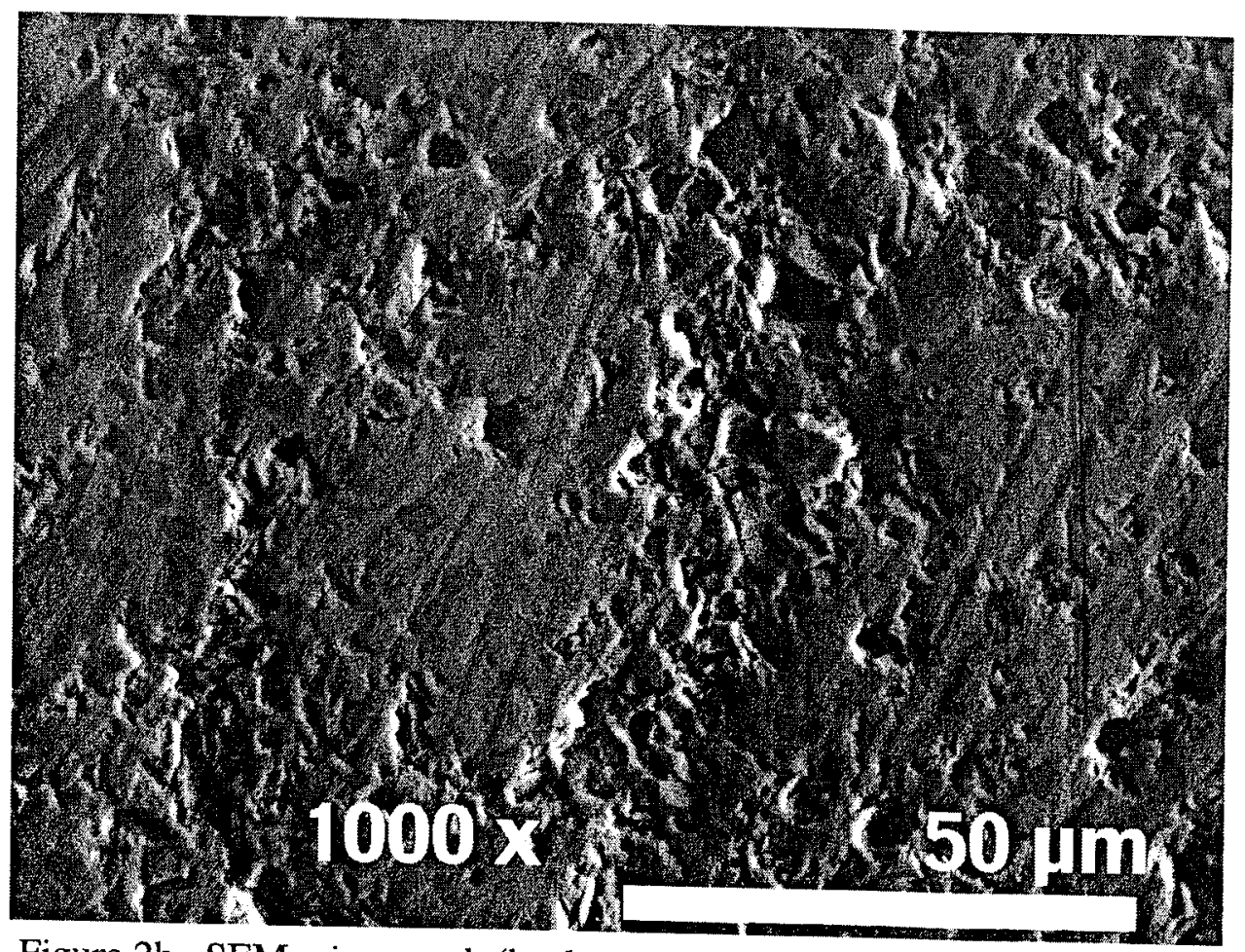

Figure 2b. SEM micrograph (backscattered electron) of an unreacted surface of the Hf-Ce-U ceramic, finished to 600-grit. 


\section{B. MCC-1 Test Procedure}

Tests discussed in this study were conducted according to the MCC-1 procedure [ASTM19981, with modifications as described in this report. All test vessels were cleaned according to a common procedure, given in Appendix A. Tests were started by sealing each ceramic wafer in a 22-mL Teflon ${ }^{\circledR}$ (PDA, Savillex) vessel with about $18 \mathrm{~g}$ of deionized water (DIW). The vessels were then placed in a constant-temperature oven at $90^{\circ} \mathrm{C}$ for the appropriate time period. The test durations were $1,3,5,7$, and 14 days. The geometric surface-area-to-leachant ratio (S/V) for these tests was about $10 \mathrm{~m}^{-1}$. At the end of the test, the leachate was removed from the vessel, and an aliquot was analyzed for $\mathrm{pH}$. The remaining leachate was acidified with a few drops of high-purity $\mathrm{HNO}_{3}$ and analyzed for cation concentrations by means of inductively coupled plasma-mass spectrometry (ICP-MS). The ceramic sample was removed and archived. The test vessel was rinsed, filled with $5 \% \mathrm{HNO}_{3}$, and placed in a $90^{\circ} \mathrm{C}$ oven for at least 16 hours. This "acid strip" solution, which contains any material fixed on the vessel wall, was analyzed for cations by using ICP-MS.

\section{Calculation of Normalized Mass Losses}

The average [NL(i)] values for MCC-1 tests were calculated to reflect the extent of corrosion of the ceramic materials. The calculation method is shown in equations 1 through 5:

$$
\mathrm{C}_{\mathrm{tl}}=\mathrm{C}_{\mathrm{ml}}-\mathrm{C}_{\mathrm{bl}}
$$

Where $\mathrm{C}_{\mathrm{t}}$ is the total concentration of an element in the leachate released from the ceramic, $\mathrm{C}_{\mathrm{ml}}$ is the measured concentration of an element in the leachate, $\mathrm{C}_{\mathrm{bl}}$ is the concentration of an element in the leachate from a blank test.

$$
\mathrm{C}_{\mathrm{ta}}=\mathrm{C}_{\mathrm{ma}}-\mathrm{C}_{\mathrm{ba}}
$$

Where $C_{t a}$ is the total concentration of an element in the acid strip solution released from the ceramic, $\mathrm{C}_{\mathrm{ma}}$ is the measured concentration of an element in the acid strip solution, $\mathrm{C}_{\mathrm{ba}}$ is the concentration of an element in the acid strip solution from a blank test.

$$
\mathrm{M}_{1}=\mathrm{C}_{\mathrm{t} 1} * \mathrm{~V}_{\mathrm{l}}
$$

Where $M_{1}$ is the mass of an element in the leachate, and $V_{1}$ is the volume of the leachate.

$$
\mathrm{M}_{\mathrm{a}}=\mathrm{C}_{\mathrm{ta}} * \mathrm{~V}_{\mathrm{a}} \text {, }
$$


Where $\mathrm{M}_{\mathrm{a}}$ is the mass of an element in the acid strip solution and $\mathrm{V}_{\mathrm{a}}$ is the volume of the acid strip solution.

$$
\mathrm{NL}(\mathrm{i})=\left(\mathrm{M}_{\mathrm{a}}+\mathrm{M}_{1}\right) /\left(\mathrm{S} * \mathrm{f}_{\mathrm{i}}\right),
$$

Where NL(i) is the normalized mass loss based on element $i, S$ is the geometric surface area of the ceramic test sample and $f_{i}$ is the mass fraction of element $i$ in the ceramic.

The uncertainty of the blank-corrected concentrations is estimated to be about $21 \%$, combining $15 \%$ estimated uncertainty for each of the concentrations measured from blanks and test solutions. The uncertainty of the NL measurements was estimated to be about $33 \%$ for the values calculated from tests with the baseline and impurity ceramics. This value includes $15 \%$ uncertainties for $\mathrm{C}_{\mathrm{ml}}, \mathrm{C}_{\mathrm{bl}}, \mathrm{C}_{\mathrm{ma}}$, and $\mathrm{C}_{\mathrm{ba}}, 10 \%$ for $\mathrm{f}_{\mathrm{i}}$ derived from batch chemical weights, and $10 \%$ for $\mathrm{S}$.

The normalized loss [NL(i)] values reflect the amount of ceramic dissolved, based on the release of different elements, during corrosion tests. If a material dissolves congruently, then the NL values based on all elements will be similar. On the other hand, if an element is preferentially released, then the NL value based on that element will be relatively high, and if an element is preferentially retained, then the NL value based on that element will be relatively low. In addition, if a material dissolves congruently and any of the released elements precipitate, then the NL value based on the precipitated elements must be relatively low. 


\section{RESULTS AND DISCUSSION}

\section{A. Blank Test Concentrations}

All corrosion tests for this study were conducted in Teflon ${ }^{\circledR}$ test vessels. The vessels used in the Hf-Ce-Ce tests had been previously used in glass corrosion tests, and had been cleaned according to the MCC-1 procedure (Appendix A). The vessels used in the Hf-Ce-U tests were new, and were cleaned according to the same procedure.

Elemental concentrations from the blank tests using four types of vessels are shown in Table 2. These data show that the background concentrations for tests in used Teflon ${ }^{\circledR}$ vessels are slightly higher in $\mathrm{Ca}$ and $\mathrm{U}$ than for tests in new Teflon ${ }^{\circledR}$ vessels. In addition, tests with stainless steel vessels have a significantly higher background than tests with Teflon ${ }^{\circledR}$ vessels, particularly with respect to $\mathrm{Ca}$ and $\mathrm{Ti}$.

Blank tests were carried out in parallel with both the Hf-Ce-Ce and the Hf-Ce-U ceramic tests. The results of the blank tests were used to quantify the background for the samplecontaining tests. As indicated in equations 1 and 2, the averages of the elemental concentrations obtained from the blank tests were subtracted from the total concentrations measured in test solutions. This calculation gives the amount of the element leached from the ceramic in the test. 
Table 2. Averaged concentrations, from blank tests in stainless steel and Teflon ${ }^{\circledR}$ test vessels.

$\begin{array}{ccccc} & \begin{array}{c}\text { Teflon } \\ \text { Used }^{\circledR}\end{array} & \begin{array}{c}\text { Teflon }^{\circledR} \text { - } \\ \text { New }^{2}\end{array} & \begin{array}{c}\text { 304L Stainless } \\ \text { Steel-Used }\end{array} & \begin{array}{c}\text { 304L Stainless } \\ \text { Steel-New }\end{array} \\ \text { Ca-leachate } & 41 & 38 & 800 & 33 \\ \text { Ca-acid strip } & 48 & 40 & 140 & 120 \\ \text { Ti-leachate } & 0.3 & <0.95 & 4.5 & 0.26 \\ \text { Ti-acid strip } & 0.62 & <0.95 & 11 & 8 \\ \text { Hf-leachate } & <0.02 & <0.02 & <0.03 & <0.02 \\ \text { Hf-acid strip } & <0.02 & <0.02 & <0.03 & <0.03 \\ \text { Ce-leachate } & 0.017 & <0.01 & \mathrm{ND}^{5} & <0.03 \\ \text { Ce-acid strip } & 0.31 & <0.01 & \mathrm{ND} & \mathrm{ND} \\ & & & & \text { ND } \\ \text { U-leachate } & 0.41 & <0.01 & 0.15 & \mathrm{ND} \\ \text { U-acid strip } & 0.16 & <0.01 & 0.15 & \text { ND } \\ \text { Gd-leachate } & 0.006 & <0.04 & 0.39 & \text { ND } \\ \text { Gd-acid strip } & 0.013 & <0.04 & 0.33 & \end{array}$

${ }^{1}$ From tests conducted in used vessels in parallel with Hf-Ce-Ce ceramic tests.

${ }^{2}$ From tests conducted in new vessels in parallel with $\mathrm{Hf}-\mathrm{Ce}-\mathrm{U}$ ceramic tests.

${ }^{3}$ From tests conducted in a study of the effect of impurities on ceramic corrosion [BAKEL-1999b].

${ }^{4}$ From a study of short-term test background concentrations [BAKEL-2000].

${ }^{5} \mathrm{ND}=$ not determined.

\section{B. Tests with Hf-Ce-Ce Ceramic}

A set of triplicate $\mathrm{MCC}-1$ tests at $90^{\circ} \mathrm{C}$ in used Teflon ${ }^{\circledR}$ vessels was conducted along with triplicate blank tests. The normalized mass loss values based on several elements for the 240 -grit and for the 600-grit surface finish tests are shown in Table 3 and plotted in Fig. 3. The values for $\mathrm{NL}(\mathrm{Ca}), \mathrm{NL}(\mathrm{Ti}), \mathrm{NL}(\mathrm{Ce})$, and $\mathrm{NL}(\mathrm{Gd})$ are all well above the detection limit, while the average values for $\mathrm{NL}(\mathrm{Hf})$ are only about twice the detection limit. The average values with the standard deviations for all of the normalized loss values overlap between these two sets of tests. Therefore, the two surface finishes lead to no detectable differences in these tests. 
Table 3. Results of three-day, $90^{\circ} \mathrm{C}$ MCC- 1 tests in DIW with a Hf-Ce-Ce titanate ceramic at two different surface finishes $\left(\mathrm{g} / \mathrm{m}^{2}\right)$

\begin{tabular}{clllll} 
Finish & $\mathrm{NL}(\mathrm{Ca})$ & $\mathrm{NL}(\mathrm{Ti})$ & $\mathrm{NL}(\mathrm{Gd})$ & $\mathrm{NL}(\mathrm{Hf})$ & $\mathrm{NL}(\mathrm{Ce})$ \\
240 Grit & 0.12 & $3.6 \times 10^{-4}$ & $3.6 \times 10^{-4}$ & $<3 \times 10^{-8}$ & $6.5 \times 10^{-5}$ \\
& 0.14 & $1.5 \times 10^{-4}$ & $4.5 \times 10^{-4}$ & $<3 \times 10^{-8}$ & $4.0 \times 10^{-5}$ \\
& 0.082 & $9.4 \times 10^{-5}$ & $2.9 \times 10^{-4}$ & $7.5 \times 10^{-8}$ & $1.8 \times 10^{-5}$ \\
& & & & & \\
Average & 0.11 & $2 \times 10^{-4}$ & $3.7 \times 10^{-4}$ & & $4 \times 10^{-5}$ \\
Standard & 0.03 & $1 \times 10^{-4}$ & $8 \times 10^{-5}$ & & $2 \times 10^{-5}$ \\
deviation & & & & & \\
Detection & 0.037 & $5.8 \times 10^{-5}$ & $9.6 \times 10^{-6}$ & $3 \times 10^{-8}$ & $7 \times 10^{-6}$ \\
limit & & & & & \\
\hline 600 Grit & 0.043 & $2.9 \times 10^{-5}$ & $5.9 \times 10^{-4}$ & $<3 \times 10^{-8}$ & $1.3 \times 10^{-4}$ \\
& 0.063 & $6.4 \times 10^{-5}$ & $6.2 \times 10^{-4}$ & $<3 \times 10^{-8}$ & $2.4 \times 10^{-4}$ \\
& 0.113 & $1.6 \times 10^{-4}$ & $3.4 \times 10^{-4}$ & $<3 \times 10^{-8}$ & $7.2 \times 10^{-5}$ \\
& & & & & $1.5 \times 10^{-4}$ \\
Average & 0.07 & $9 \times 10^{-5}$ & $5 \times 10^{-4}$ & & $9 \times 10^{-5}$ \\
$\begin{array}{c}\text { Standard } \\
\text { deviation }\end{array}$ & 0.04 & $7 \times 10^{-5}$ & $2 \times 10^{-4}$ & & $7 \times 10^{-6}$ \\
Detection & 0.037 & $5.8 \times 10^{-5}$ & $9.6 \times 10^{-6}$ & $3 \times 10^{-8}$ & \\
limit & & & & & \\
\hline
\end{tabular}




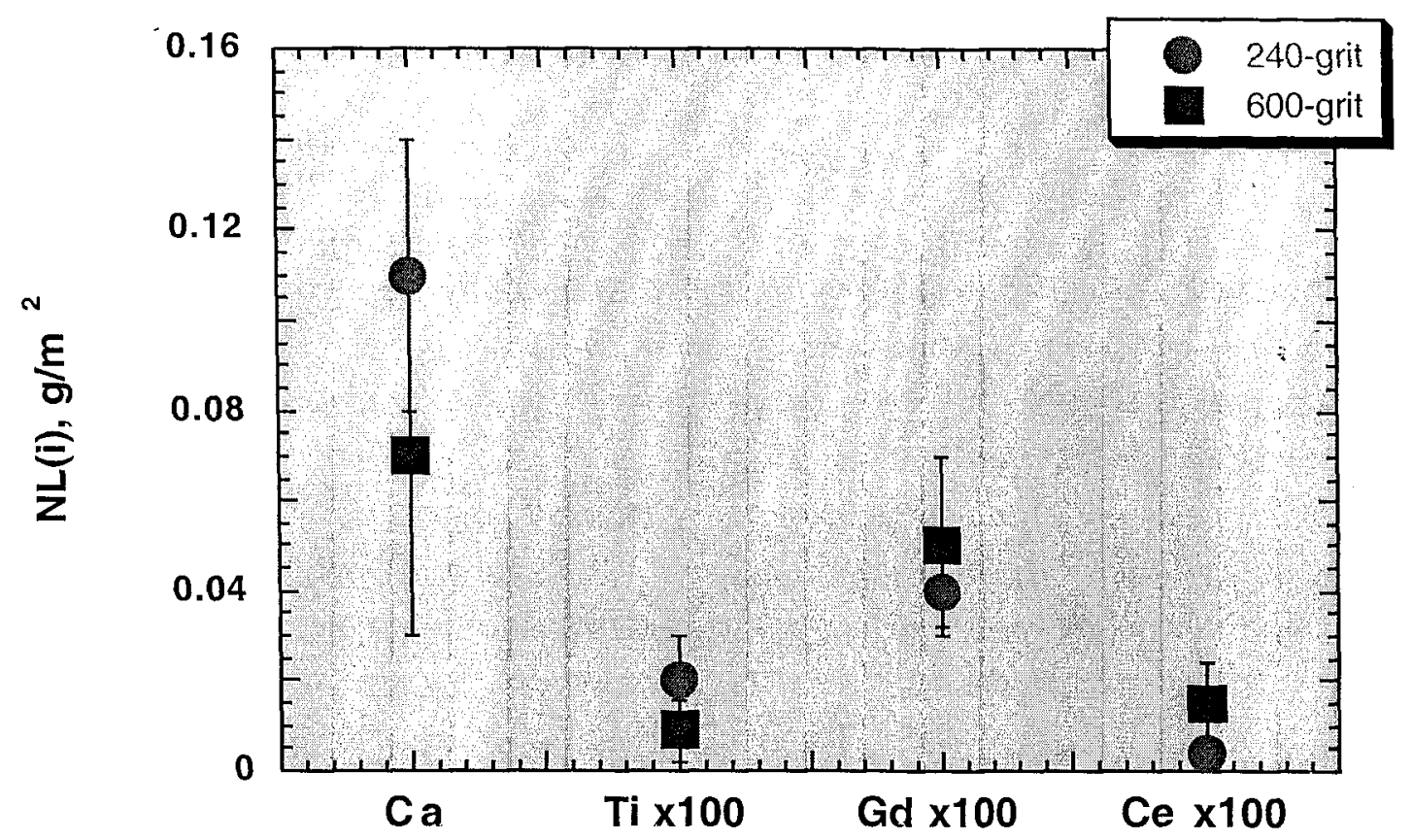

Figure 3. Plot of the average normalized mass loss values from tests with the $\mathrm{Hf}$-Ce-Ce ceramic at two different surface finishes. The error bars represent the standard deviations Note the different scales for different elements. Data are listed in Table 3.

\section{Tests with Hf-Ce-U Ceramic}

A set of $30 \mathrm{MCC}-1$ type tests was conducted with a baseline Hf-Ce-U ceramic, along with 30 blank tests. Triplicate tests and blanks were run for 1, 3, 5, 7, and 14 days. Identical test series were conducted with ceramics finished to 240 -grit and 600-grit. The normalized mass loss values based on several elements for 240-grit and for 600-grit surface finish tests are shown in Tables 4 and 5. The values for NL(Ca), NL(Gd), NL(Ce), and NL(U) are all well above the detection limit, while the average values for NL(Ti) and NL(Hf) are only slightly above the detection limit.

The average normalized releases and their standard deviations shown as a function of the test duration in Fig. 4. The normalized mass loss values from 600-grit tests overlap the normalized mass loss values from 240 -grit tests. Therefore, the two surface finishes lead to no detectable differences in these tests. 


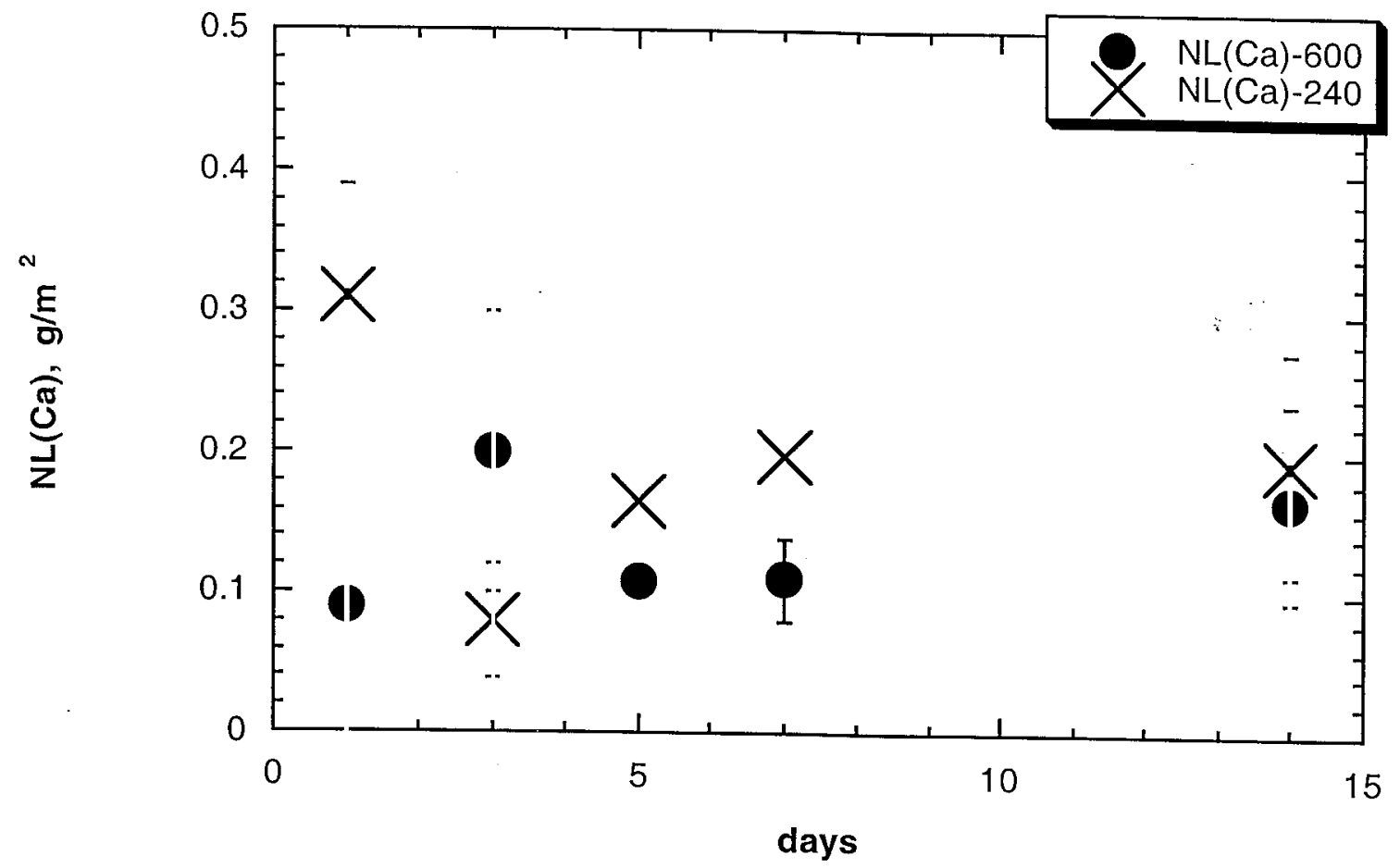

Figure 4a. Plot of average NL(Ca) values as a function of reaction time in MCC-1 tests with the Hf-Ce-U ceramic. The error bars represent the standard deviations. 


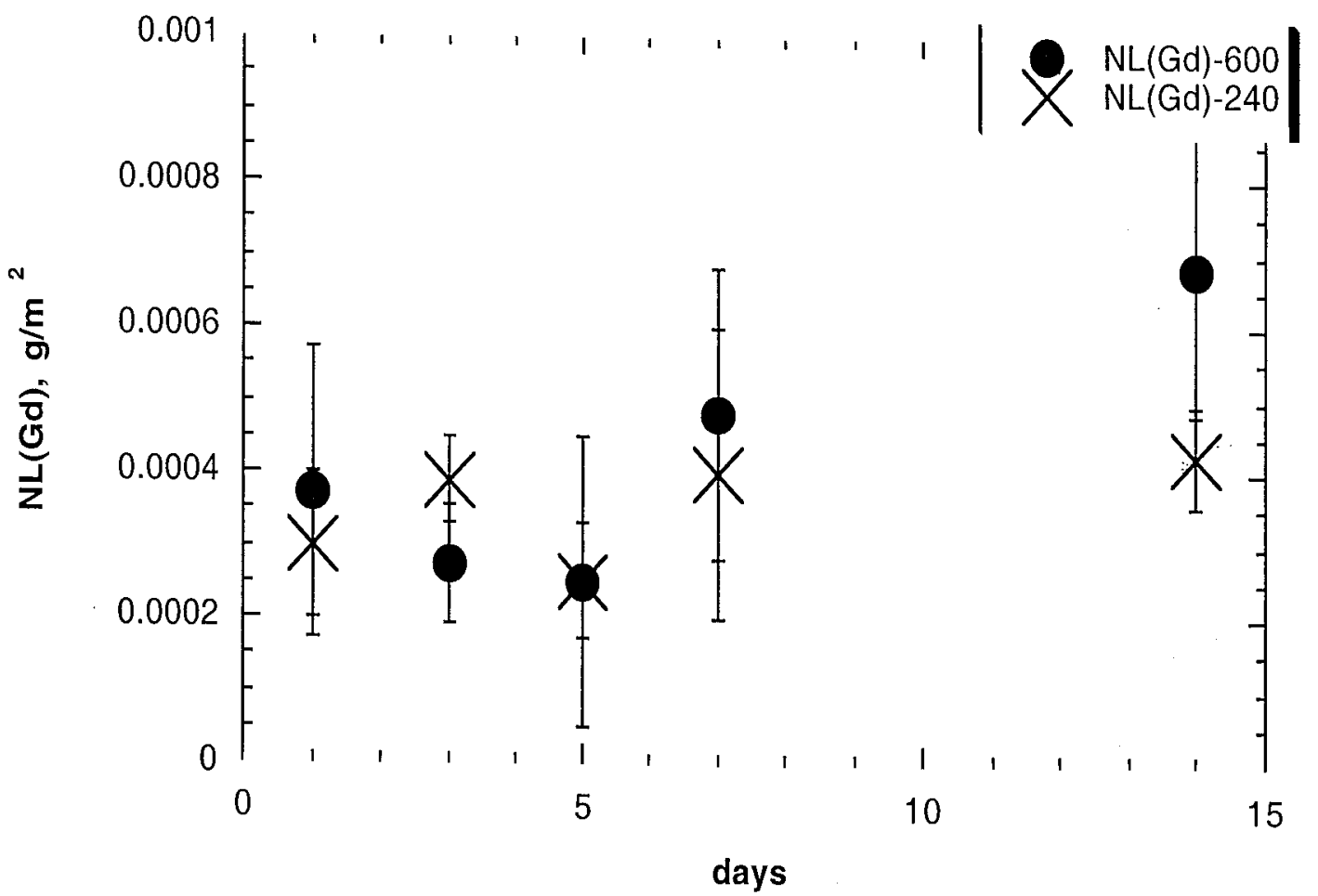

Figure 4b. Plot of average NL(Gd) values as a function of reaction time in MCC-1 tests with the Hf-Ce-U ceramic. The error bars represent the standard deviations.

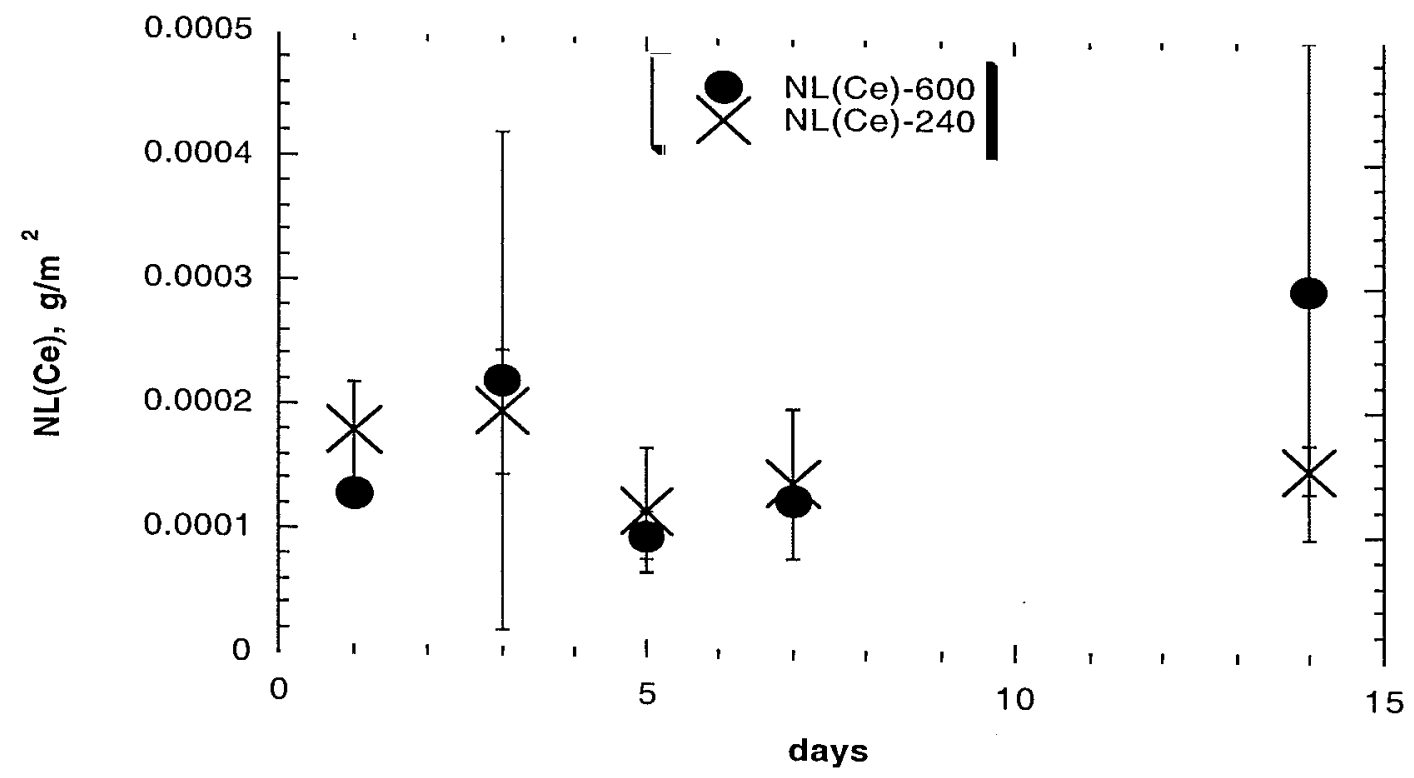

Figure 4c. Plot of average NL(Ce) values as a function of reaction time in MCC-1 tests with the Hf-Ce-U ceramic. The error bars represent the standard deviations. 


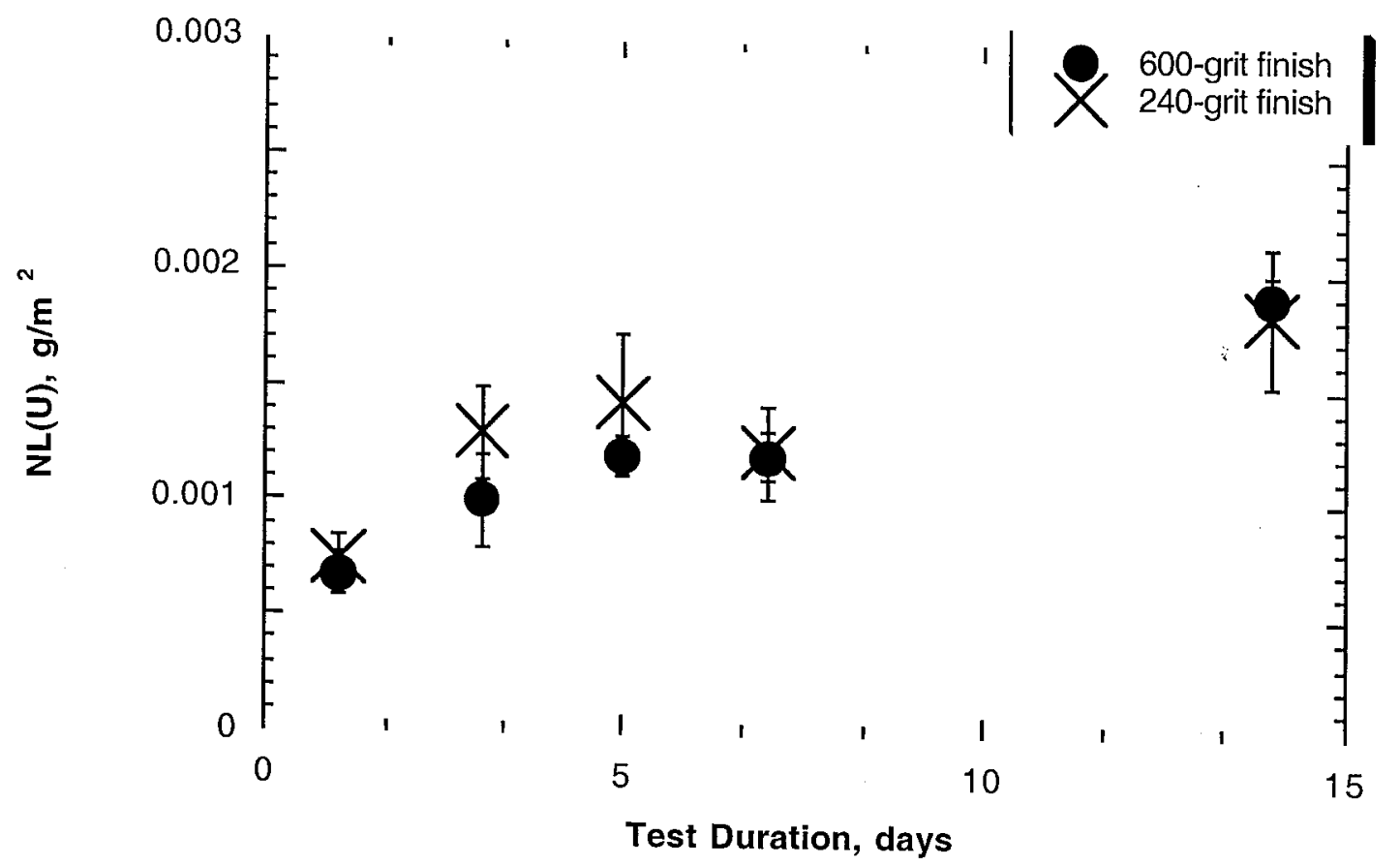

Figure 4d. Plot of average $\mathrm{NL}(\mathrm{U})$ values as a function of reaction time in MCC-1 tests with the Hf-Ce-U ceramic. The error bars represent the standard deviations. 
Table 4. Results of 600 -grit, $90^{\circ} \mathrm{C} \mathrm{MCC}-1$ tests at several durations in DIW with a Hf-Ce-U titanate ceramic $\left(\mathrm{g} / \mathrm{m}^{2}\right)$

\begin{tabular}{|c|c|c|c|c|c|c|}
\hline & $\mathrm{NL}(\mathrm{Ca})$ & NL(Ti) & $\mathrm{NL}(\mathrm{Gd})$ & NL(Hf) & $\mathrm{NL}(\mathrm{Ce})$ & NL(U) \\
\hline 1 day & 0.101 & $<7 \times 10^{-4}$ & $3.7 \times 10^{-4}$ & $<4 \times 10^{-5}$ & $1.3 \times 10^{-4}$ & $7.4 \times 10^{-4}$ \\
\hline 1 day & 0.110 & $<7 \times 10^{-4}$ & $4.9 \times 10^{-4}$ & $<4 \times 10^{-5}$ & $1.9 \times 10^{-4}$ & $7.2 \times 10^{-4}$ \\
\hline 1 day & 0.057 & $<7 \times 10^{-4}$ & $1.6 \times 10^{-4}$ & $<4 \times 10^{-5}$ & $7.5 \times 10^{-5}$ & $5.7 \times 10^{-4}$ \\
\hline Average & 0.09 & & $3 \times 10^{-4}$ & & $1.3 \times 10^{-4}$ & $6.8 \times 10^{-4}$ \\
\hline $\begin{array}{l}\text { Standard } \\
\text { deviation }\end{array}$ & 0.03 & & $2 \times 10^{-4}$ & & $6 \times 10^{-5}$ & $\because 9 \times 10^{-5}$ \\
\hline 3 day & 0.276 & $<7 \times 10^{-4}$ & $3.6 \times 10^{-4}$ & $<4 \times 10^{-5}$ & $1.4 \times 10^{-4}$ & $1.1 \times 10^{-3}$ \\
\hline 3 day & 0.095 & $<7 \times 10^{-4}$ & $2.3 \times 10^{-4}$ & $<4 \times 10^{-5}$ & $4.0 \times 10^{-4}$ & $9.5 \times 10^{-4}$ \\
\hline 3 day & $<0.05$ & $<7 \times 10^{-4}$ & $2.3 \times 10^{-4}$ & $<4 \times 10^{-5}$ & $1.2 \times 10^{-4}$ & $9.3 \times 10^{-4}$ \\
\hline Average & 0.2 & & $2.7 \times 10^{-4}$ & & $2 \times 10^{-4}$ & $1 \times 10^{-3}$ \\
\hline $\begin{array}{l}\text { Standard } \\
\text { deviation }\end{array}$ & 0.1 & & $8 \times 10^{-5}$ & & $2 \times 10^{-4}$ & $1 \times 10^{-4}$ \\
\hline 5 day & $<0.05$ & $<7 \times 10^{-4}$ & $1.8 \times 10^{-4}$ & $<4 \times 10^{-5}$ & $7.7 \times 10^{.5}$ & $1.1 \times 10^{-3}$ \\
\hline 5 day & 0.108 & $<7 \times 10^{-4}$ & $2.4 \times 10^{-4}$ & $<4 \times 10^{-5}$ & $1.0 \times 10^{-4}$ & $1.3 \times 10^{-3}$ \\
\hline 5 day & $<0.05$ & $<7 \times 10^{-4}$ & $3.3 \times 10^{-4}$ & $<4 \times 10^{-5}$ & $1.1 \times 10^{-4}$ & $1.2 \times 10^{-3}$ \\
\hline Average & 0.108 & & $2.5 \times 10^{-4}$ & & $9 \times 10^{-5}$ & $1.2 \times 10^{-3}$ \\
\hline $\begin{array}{l}\text { Standard } \\
\text { deviation }\end{array}$ & & & $8 \times 10^{-5}$ & & $2 \times 10^{-5}$ & $1 \times 10^{-4}$ \\
\hline 7 day & $<0.05$ & $<7 \times 10^{-4}$ & $4.5 \times 10^{-4}$ & $<4 \times 10^{-5}$ & $1.3 \times 10^{-4}$ & $1.4 \times 10^{-3}$ \\
\hline 7 day & 0.088 & $<7 \times 10^{-4}$ & $3.5 \times 10^{-4}$ & $<4 \times 10^{-5}$ & $1.3 \times 10^{-4}$ & $1.2 \times 10^{-3}$ \\
\hline 7 day & 0.130 & $<7 \times 10^{-4}$ & $7.0 \times 10^{-4}$ & $<4 \times 10^{-5}$ & $1.2 \times 10^{-4}$ & $1.1 \times 10^{-3}$ \\
\hline Average & 0.11 & & $5 \times 10^{-4}$ & & $1.3 \times 10^{-4}$ & $1.2 \times 10^{-3}$ \\
\hline $\begin{array}{l}\text { Standard } \\
\text { deviation }\end{array}$ & 0.03 & & $2 \times 10^{-4}$ & & $6 \times 10^{-6}$ & $1 \times 10^{-4}$ \\
\hline 14 day & 0.114 & $<7 \times 10^{-4}$ & $8.2 \times 10^{-4}$ & $<4 \times 10^{-5}$ & $3.2 \times 10^{-4}$ & $2.0 \times 10^{-3}$ \\
\hline 14 day & 0.246 & $<7 \times 10^{-4}$ & $7.3 \times 10^{-4}$ & $<4 \times 10^{-5}$ & $1.3 \times 10^{-4}$ & $1.8 \times 10^{-3}$ \\
\hline 14 day & 0.141 & $<7 \times 10^{-4}$ & $5.0 \times 10^{-4}$ & $<4 \times 10^{-5}$ & $4.4 \times 10^{-4}$ & $1.9 \times 10^{-3}$ \\
\hline Average & 0.17 & & $7 \times 10^{-4}$ & & $3 \times 10^{-4}$ & $1.9 \times 10^{-3}$ \\
\hline $\begin{array}{l}\text { Standard } \\
\text { deviation }\end{array}$ & 0.07 & & $2 \times 10^{-4}$ & & $2 \times 10^{-4}$ & $1 \times 10^{-4}$ \\
\hline $\begin{array}{c}\text { Detection } \\
\text { limit }\end{array}$ & 0.05 & $<7 \times 10^{-4}$ & $9.0 \times 10^{-5}$ & $<4 \times 10^{-5}$ & $3 \times 10^{-5}$ & $1 \times 10^{-5}$ \\
\hline
\end{tabular}


Table 5. Results of 240 -grit, $90^{\circ} \mathrm{C}$ MCC- 1 tests at several durations in DIW with a Hf-Ce-U titanate ceramic $\left(\mathrm{g} / \mathrm{m}^{2}\right)$

\begin{tabular}{|c|c|c|c|c|c|c|}
\hline & $\mathrm{NL}(\mathrm{Ca})$ & NL(Ti) & $\mathrm{NL}(\mathrm{Gd})$ & NL(Hf) & $\mathrm{NL}(\mathrm{Ce})$ & $\mathrm{NL}(\mathrm{U})$ \\
\hline 1 day & 0.311 & $<7 \times 10^{-4}$ & $2.4 \times 10^{-4}$ & $<4 \times 10^{-5}$ & $1.9 \times 10^{-4}$ & $6.3 \times 10^{-4}$ \\
\hline 1 day & $<0.05$ & $<7 \times 10^{-4}$ & $<9 \times 10^{-5}$ & $<4 \times 10^{-5}$ & $1.4 \times 10^{-4}$ & $7.8 \times 10^{-4}$ \\
\hline 1 day & $<0.05$ & $<7 \times 10^{-4}$ & $<9 \times 10^{-5}$ & $<4 \times 10^{-5}$ & $2.1 \times 10^{-4}$ & $8.3 \times 10^{-4}$ \\
\hline Average & 0.31 & & $2.4 \times 10^{-4}$ & & $1.8 \times 10^{-4}$ & $8 \times 10^{-4}$ \\
\hline $\begin{array}{l}\text { Standard } \\
\text { deviation }\end{array}$ & & & & & $4 \times 10^{-5}$ & $1 \times 10^{-4}$ \\
\hline 3 day & 0.052 & $<7 \times 10^{-4}$ & $3.8 \times 10^{-4}$ & $<4 \times 10^{-5}$ & $1.6 \times 10^{-4}$ & $1.1 \times 10^{-3}$ \\
\hline 3 day & 0.110 & $<7 \times 10^{-4}$ & $3.3 \times 10^{-4}$ & $<4 \times 10^{-5}$ & $1.9 \times 10^{-4}$ & $1.5 \times 10^{-3}$ \\
\hline 3 day & $<0.05$ & $<7 \times 10^{-4}$ & $4.5 \times 10^{-4}$ & $<4 \times 10^{-5}$ & $2.5 \times 10^{-4}$ & $1.3 \times 10^{-3}$ \\
\hline Average & 0.08 & & $3.9 \times 10^{-4}$ & & $2.0 \times 10^{-4}$ & $1.3 \times 10^{-3}$ \\
\hline $\begin{array}{l}\text { Standard } \\
\text { deviation }\end{array}$ & 0.04 & & $6 \times 10^{-5}$ & & $5 \times 10^{-5}$ & $2 \times 10^{-4}$ \\
\hline 5 day & 0.116 & $<7 \times 10^{-4}$ & $2.1 \times 10^{-4}$ & $<4 \times 10^{-5}$ & $7.8 \times 10^{-5}$ & $1.1 \times 10^{-3}$ \\
\hline 5 day & $<0.05$ & $<7 \times 10^{-4}$ & $2.1 \times 10^{-4}$ & $<4 \times 10^{-5}$ & $9.7 \times 10^{-5}$ & $1.4 \times 10^{-3}$ \\
\hline 5 day & $<0.05$ & $<7 \times 10^{-4}$ & $5.8 \times 10^{-4}$ & $<4 \times 10^{-5}$ & $1.8 \times 10^{-4}$ & $1.8 \times 10^{-3}$ \\
\hline Average & 0.12 & & $3 \times 10^{-4}$ & & $1.2 \times 10^{-4}$ & $1.4 \times 10^{-3}$ \\
\hline $\begin{array}{l}\text { Standard } \\
\text { deviation }\end{array}$ & & & $2 \times 10^{-4}$ & & $5 \times 10^{-5}$ & $3 \times 10^{-4}$ \\
\hline 7 day & 0.198 & $<7 \times 10^{-4}$ & $5.2 \times 10^{-4}$ & $<4 \times 10^{-5}$ & $2.1 \times 10^{-4}$ & $1.4 \times 10^{-3}$ \\
\hline 7 day & $<0.05$ & $<7 \times 10^{-4}$ & $2.2 \times 10^{-4}$ & $<4 \times 10^{-5}$ & $1.2 \times 10^{-4}$ & $1.1 \times 10^{-3}$ \\
\hline 7 day & 0.058 & $<7 \times 10^{-4}$ & $2.6 \times 10^{-4}$ & $<4 \times 10^{-5}$ & $8.7 \times 10^{-5}$ & $1.2 \times 10^{-3}$ \\
\hline Average & 0.13 & & $4 \times 10^{-4}$ & & $1.4 \times 10^{-4}$ & $1.2 \times 10^{-3}$ \\
\hline $\begin{array}{l}\text { Standard } \\
\text { deviation }\end{array}$ & 0.09 & & $2 \times 10^{-4}$ & & $6 \times 10^{-5}$ & $2 \times 10^{-4}$ \\
\hline 14 day & 0.131 & $<7 \times 10^{-4}$ & $5.0 \times 10^{-4}$ & $<4 \times 10^{-5}$ & $1.6 \times 10^{-4}$ & $2.0 \times 10^{-3}$ \\
\hline 14 day & 0.182 & $<7 \times 10^{-4}$ & $4.2 \times 10^{-4}$ & $<4 \times 10^{-5}$ & $1.7 \times 10^{-4}$ & $1.5 \times 10^{-3}$ \\
\hline 14 day & 0.282 & $<7 \times 10^{-4}$ & $3.6 \times 10^{-4}$ & $<4 \times 10^{-5}$ & $1.4 \times 10^{-4}$ & $2.0 \times 10^{-3}$ \\
\hline Average & 0.20 & & $4.3 \times 10^{-4}$ & & $1.5 \times 10^{-4}$ & $1.8 \times 10^{-3}$ \\
\hline $\begin{array}{l}\text { Standard } \\
\text { deviation }\end{array}$ & 0.08 & & $7 \times 10^{-5}$ & & $2 \times 10^{-5}$ & $3 \times 10^{-4}$ \\
\hline $\begin{array}{c}\text { Detection } \\
\text { limit }\end{array}$ & 0.05 & $<7 \times 10^{-4}$ & $9 \times 10^{-5}$ & $4 \times 10^{-5}$ & $3 \times 10^{-5}$ & $1 \times 10^{-4}$ \\
\hline
\end{tabular}




\section{Comparison with Previous Results}

The normalized mass loss values measured in the three-day MCC-1 tests described in this study suggest that these materials might be somewhat more durable than the previously studied titanate ceramics. Tables 6 and 7 summarize the results of 3-day MCC-1 tests with several different titanate ceramics. The normalized mass loss values reported in Table 6 are in grams of ceramic per total square meter. In Table 7 , the units are in moles ceramic per total surface area. The moles of ceramic were calculated by dividing the values in Table 6 by the average molecular weight of the ceramic. The average molecular weights of the ceramics shown in Table 7 are the weighted averages of the molecular weights of the chemicals that make up each ceramic.

Table 6. Results from 3-day MCC-1 tests with various titanate ceramics.

\begin{tabular}{|c|c|c|c|c|c|c|c|c|c|c|}
\hline & Ceramic & $\begin{array}{l}\text { Surface } \\
\text { Finish }\end{array}$ & $\begin{array}{c}\mathrm{NL}(\mathrm{Ca}) \\
\left(\mathrm{g} / \mathrm{m}^{2}\right)\end{array}$ & $\begin{array}{c}\mathrm{NL}(\mathrm{Pu}) \\
\left(\mathrm{g} / \mathrm{m}^{2}\right)\end{array}$ & $\begin{array}{c}\mathrm{NL}(\mathrm{Ce}) \\
\left(\mathrm{g} / \mathrm{m}^{2}\right)\end{array}$ & $\begin{array}{l}\mathrm{NL}(\mathrm{U}) \\
\left(\mathrm{g} / \mathrm{m}^{2}\right)\end{array}$ & $\begin{array}{l}\text { Density } \\
\left(\mathrm{g} / \mathrm{cm}^{3}\right)\end{array}$ & $\begin{array}{l}\text { Theoretical } \\
\text { Density } \\
\left(\mathrm{g} / \mathrm{cm}^{3}\right)\end{array}$ & $\begin{array}{c}\% \text { Theoretical } \\
\text { Density }\end{array}$ & Reference \\
\hline 1 & $\begin{array}{l}\text { Zirconolite- } \\
\text { rich }\end{array}$ & 240 & 2.1 & 0.005 & - & - & 4.8 & 4.5 & 107 & [BAKEL-1999a] \\
\hline 2 & $\begin{array}{l}\text { Pyrochlore- } \\
\text { rich baseline- } \\
\text { AO }\end{array}$ & 240 & 0.8 & 0.0004 & - & 0.007 & 5.5 & 6.1 & 90 & [BAKEL-1999c] \\
\hline 3 & $\begin{array}{c}\text { Pyrochlore- } \\
\text { rich baseline- } \\
\text { A0 }\end{array}$ & 240 & 1.0 & - & 0.01 & 0.01 & 5.4 & 6.0 & 90 & [BAKEL-1999b] \\
\hline 4 & $\begin{array}{c}\text { Pyrochlore- } \\
\text { rich baseline- } \\
\text { A0 }\end{array}$ & 600 & $\begin{array}{c}0.06- \\
0.2\end{array}$ & - & 0.03 & 0.006 & 5.0 & - & - & $\begin{array}{c}\text { [CRAWFORD- } \\
\text { 1999] }\end{array}$ \\
\hline 5 & $\begin{array}{c}\text { Pyrochlore- } \\
\text { rich inpurity- } \\
\text { B3-13 }\end{array}$ & 240 & 0.9 & 0.002 & - & 0.008 & 4.9 & 6.3 & 78 & [BAKEL-1999c] \\
\hline 6 & $\mathrm{Hf}-\mathrm{Ce}-\mathrm{Ce}$ & 240 & 0.1 & - & 0.0004 & - & 4.9 & 5.0 & 98 & Current study \\
\hline 7 & $\mathrm{Hf}-\mathrm{Ce}-\mathrm{Ce}$ & 600 & 0.1 & - & 0.0002 & - & 4.9 & 5.0 & 98 & Current study \\
\hline 8 & Hf-Ce-IJ & 240 & 0.1 & - & 0.0002 & 0.001 & 5.8 & 5.8 & 100 & Current study \\
\hline 9 & $\mathrm{Hf}-\mathrm{Ce}-\mathrm{U}$ & 600 & 0.2 & - & 0.0002 & 0.001 & 5.8 & 5.8 & 100 & Current study \\
\hline
\end{tabular}


Table 7. Results from 3-day MCC-1 tests with various titanate ceramics.

Normalized mass loss values have been converted to units of $\mathrm{g}$ ceramic $/ \mathrm{m}^{2}$.

\begin{tabular}{|c|c|c|c|c|c|c|c|}
\hline & Ceramic & $\begin{array}{l}\text { Surface } \\
\text { Finish }\end{array}$ & $\begin{array}{l}\text { Molecular weight } \\
\text { (g/mole ceramic) }\end{array}$ & $\begin{array}{c}\mathrm{NL}(\mathrm{Ca})(\mathrm{moles} \\
\left.\text { ceramic } / \mathrm{m}^{2}\right)\end{array}$ & $\begin{array}{c}\mathrm{NL}(\mathrm{Pu})(\mathrm{moles} \\
\text { ceramic/m²) }\end{array}$ & $\begin{array}{c}\text { NL(Ce) (moles } \\
\left.\text { ceramic } / \mathrm{m}^{2}\right)\end{array}$ & $\begin{array}{l}\mathrm{NL}(\mathrm{U})(\text { moles } \\
\left.\text { ceramic/m } / \mathrm{m}^{2}\right)\end{array}$ \\
\hline 1 & $\begin{array}{l}\text { Zirconolite- } \\
\text { rich }\end{array}$ & 240 & 142.8 & $1.5 \times 10^{-2}$ & $3.5 \times 10^{-5}$ & - & - \\
\hline 2 & $\begin{array}{l}\text { Pyrochlore- } \\
\text { rich baseline- } \\
\text { A0 }\end{array}$ & 240 & 170.7 & $4.7 \times 10^{-3}$ & $2.3 \times 10^{-6}$ & $i$ & $4.1 \times 10^{-5}$ \\
\hline 3 & $\begin{array}{c}\text { Pyrochlore- } \\
\text { rich baseline- } \\
\text { A0 }\end{array}$ & 240 & 161.2 & $0.2 \times 10^{-3}$ & - & $6.2 \times 10^{-5}$ & $6.2 \times 10^{-5}$ \\
\hline 4 & $\begin{array}{c}\text { Pyrochlore- } \\
\text { rich baseline- } \\
\text { A0 }\end{array}$ & 600 & 151.0 & $\begin{array}{c}4.0 \times 10^{-4}- \\
1.3 \times 10^{-3}\end{array}$ & - & $2.0 \times 10^{-4}$ & $4.0 \times 10^{-5}$ \\
\hline 5 & $\begin{array}{l}\text { Pyrochlore- } \\
\text { rich inpurity- } \\
\text { B3-13 }\end{array}$ & 240 & 178.7 & $5.0 \times 10^{-3}$ & $1.1 \times 10^{-5}$ & - & $4.5 \times 10^{-5}$ \\
\hline 6 & $\mathrm{Hf}-\mathrm{Ce}-\mathrm{Ce}$ & 240 & 131.7 & $7.6 \times 10^{-4}$ & - & $3.0 \times 10^{-5}$ & - \\
\hline 7 & Hf-Ce-Ce & 600 & 131.7 & $7.6 \times 10^{-4}$ & - & $1.5 \times 10^{-6}$ & - \\
\hline 8 & $\mathrm{Hf}-\mathrm{Ce}-\mathrm{U}$ & 240 & 158.6 & $6.3 \times 10^{-4}$ & - & $1.3 \times 10^{-6}$ & $6.3 \times 10^{-6}$ \\
\hline 9 & Hf-Ce-U & 600 & 158.6 & $1.3 \times 10^{-3}$ & - & $1.3 \times 10^{-6}$ & $6.3 \times 10^{-6}$ \\
\hline
\end{tabular}

The NL(Ca) value from tests with the zirconolite-rich ceramic (ceramic 1 in Table 6) was much higher than values from tests with pyrochlore-rich ceramics. Perovskite and a small amount of hollandite were present in the zirconolite-rich ceramic but not in the pyrochlore-rich ceramics. Corrosion of the relatively rapidly dissolved perovskite [LUMPKIN-1991, SMITH-1997] probably accounts for the high NL(Ca) value for the zirconolite-rich ceramic relative to the pyrochlore-rich ceramics (e.g., ceramics 2, 3 and 5).

Three of the pyrochlore-rich ceramics (ceramics 2,3 , and 5 in Table 6) have very similar $\mathrm{NL}(\mathrm{U})$ values ranging from 0.007 to $0.010 \mathrm{~g} / \mathrm{m}^{2}$. The phase assemblages of these three ceramics are similar, in particular each contains brannerite. Previous work has suggested that brannerite dissolves more rapidly than the other U-bearing phases in these ceramics, and therefore has an important effect on the NL(U) value in short-term tests [BAKEL-1999b, BOURCIER-1999, HART-1999]. 
The results of this study (ceramic 6,7,8, and 9 in Table 6) are similar to the results of tests with similar materials done at WSRC (ceramic 4 in Table 6). The NL(Ca), NL(Ce) and NL(U) values shown in Table 6 for these tests are much lower than for the other tests shown. This is somewhat unexpected. The Hf-Ce-Ce ceramic contains a significant amount of perovskite, and so it was expected to have a relatively high $\mathrm{NL}(\mathrm{Ca})$ value based on previous work [LUMPKIN-1991, SMITH-1997].

Other than the presence of perovskite in the Hf-Ce-Ce ceramic, the phase assemblages of numbers $2,3,4,6,7,8$, and 9, are similar. The phase assemblages are based on SEM examination (e.g. Figure 1) and account for the major and minor phases. However, the composition of the grain boundaries or the distribution of trace phases may vary. Because the bulk ceramic is quite durable, any changes in the corrosion behavior of trace phases or grain boundaries would be particularly important in the overall corrosion behavior of the ceramics during short-term tests.

The values of $\mathrm{NL}(\mathrm{Ca}), \mathrm{NL}(\mathrm{Pu}), \mathrm{NL}(\mathrm{Ce})$, and $\mathrm{NL}(\mathrm{U})$ for the various ceramics (Tables 6 and 7) range over more than an order of magnitude. It has been suggested that the porosity of the ceramic affects its corrosion behavior. In particular, if the porosity is greater than $8 \%$, then it can be interconnected [SHAW-1998]. Table 6 contains the measured densities for each of the ceramics considered. The theoretical density of each ceramic was calculated based on chemical composition and phase composition [EBBINGHAUS-2000]. The spreadsheet used for the theoretical density calculations was developed for pyrochlore-rich ceramics, and therefore may not be accurate for the zirconolite-rich ceramic. Three of the pyrochlore-rich ceramics (\#2, 3 and 5) have more than $8 \%$ porosity; these same ceramics have relatively high NL(Ca) and NL(U) values. The ceramics used in this study (\#6-9) have less than $8 \%$ porosity; these same ceramics have relatively low $\mathrm{NL}(\mathrm{Ca})$ and $\mathrm{NL}(\mathrm{U})$ values. The observed relationship between porosity and corrosion behavior supports the idea that ceramics with $8 \%$ or more porosity have higher normalized mass loss values in short-term tests. 


\section{RECOMMENDATIONS}

Our MCC-1 test data for Hf-Ce-Ce and Hf-Ce-U titanate ceramic monoliths reveal no measurable difference between the corrosion of monoliths finished to 240-grit and those finished to 600-grit. This result is in marked contrast to those of previous studies [OH-1991, DUSSOSSOY-1992] that showed significant effects of surface finish on the corrosion behavior of glass. We suggest that the total surface area of a ceramic monolith is dominated by pores and preparation artifacts (e.g. rip-outs), and it is not significantly affected by surface finish. On the other hand, glasses are generally less prone to rip-out.

The finer (600-grit) finish can be produced more consistently than can the coarser (240-grit) finish. In addition, surface flaws (e.g., large pores, cracks and, chips) are easier to detect if the surface has a fine finish. Therefore, we recommend that all monoliths used in short-term MCC-1 tests have a 600 -grit finish.

The tests in this study were conducted in Teflon ${ }^{\circledR}$ vessels, whereas previous short-term testing projects were conducted in $304 \mathrm{~L}$ stainless steel vessels. Data shown here suggests that the background is lower for tests conducted with Teflon ${ }^{\circledR}$ vessels than for tests conducted with stainless steel. In addition, the relatively low cost of Teflon ${ }^{\text {B }}$ vessels allow for disposal of each vessel after one use. This is particularly beneficial when testing radioactive materials.

Our experience shows that Teflon ${ }^{\circledR}$ vessels are more prone to leakage than are stainless steel vessels. The leakage can be minimized by placing the vessels in sealed secondary containers. A small amount of DIW is in the secondary containers containing. In addition, long-term tests with highly radioactive materials might result in damage to the vessel material; therefore, Teflon ${ }^{\circledR}$ vessels are probably not suitable for long-term tests. However, we believe that Teflon ${ }^{\circledR}$ vessels are suitable for short-term tests, and we plan to use them in future tests. 


\section{CONCLUSIONS}

The tests described in this report were conducted to determine whether the use of different surface finishes on the ceramic monolith affects the results of short-term MCC-1 tests. Two different, pyrochlore-rich titanate ceramics were prepared with 240- and 600-grit finishes as test samples. Series of MCC-1 tests were run in Teflon ${ }^{\circledR}$ test vessels at test durrations of 1, 3, 5, 7 , and 14 days.

The test results show that the surface finish has no measurable effect on the short-term corrosion behavior of these ceramics. Therefore, short-term MCC-1 tests conducted at different sites, using samples with different surface finishes, can be directly compared.

The normalized mass loss values calculated from short-term MCC-1 tests suggest that these Hf-Ce-Ce and Hf-Ce-U ceramics are more durable than several titanate ceramics tested in previous projects. While a definite cause cannot be determined based on available data, we suggest that the corrosion of trace phases and grain boundaries is responsible for the observed differences. The data also suggests that ceramics with less than $8 \%$ porosity yield significantly lower normalized mass loss values than ceramics with more than $8 \%$ porosity.

Based on data shown here, we recommend that future short-term MCC-1 tests be conducted with a 600 -grit finish due to its broad use and ease of inspection. Teflon ${ }^{\circledast}$ vessels are recommended over 304L stainless steel vessels for short-term MCC-1 tests due to their low cost and low background.

\section{ACKNOWLEDGMENTS}

This work was supported by the U.S. Department of Energy Office of Fissile Materials Disposition under Contract No. W-31-109-Eng-38. 


\section{REFERENCES}

ASTM-1998

"Standard Test Method for Static Leaching of Monolithic Waste Forms for Disposal of Radioactive Waste," ASTM Standard C1220-98, American Society for Testing and Materials, Philadelphia, PA (1998).

BAKEL-2000

Letter report to Henry Shaw, December 17, 2000.

BAKEL-1999a

A. J. Bakel, E. C. Buck, C. J. Mertz, D. B. Chamberlain, and S.F. Wolf, "Corrosion Behavior of a Zirconolite-Rich Ceramic," Lawrence Livermore National Laboratory, Livermore, CA Report PIP-99-045 (1999).

BAKEL-1999b

A. J. Bakel, E. C. Buck, V. N. Zyryanov, C. J. Mertz, and D. B. Chamberlain, "Characterization and Corrosion Behavior of Hf-Ce-U Ceramics Containing Impurities," Lawrence Livermore National Laboratory, Livermore, CA, Report PIP 99-077 (1999).

BAKEL-1999c

A. J. Bakel, C. J. Mertz, M. K. Nole, and D. B. Chamberlain, "Plutonium Immobilization Project-Plutonium Immobilization: Corrosion Behavior of Titanate Ceramics in Short-Term MCC-1 Tests: Results from Tests with Zirconolite-Rich, Baseline and Impurity Ceramics," Lawrence Livermore National Laboratory, Livermore, CA, Report PIP 99-102 (1999).

BOURCIER-1999

W. L. Bourcier, "Interim Report on Development of a Model to Predict Dissolution Behavior of the Titanate Waste Form in a Repository and Compilation of Data from SPFT Ceramic Dissolution Tests," Lawrence Livermore National Laboratory, Livermore, CA Report PIP-00-003 (1999).

CRAWFORD-1999

C. L. Crawford, C.R. Biddle, and N. E. Bibler, "Durability testing of Heavy-Ion-Irradiated Crystalline Ceramics," Lawrence Livermore National Laboratory, Livermore, CA, Report PIP-99-100 (1999). 


\section{DUSSOSSOY -1992}

J. L. Dussossoy, C. Dubois, E. Vernaz, and A. Chambaudet, "Effect of Surface Finish on Nuclear Glass Dissolution Rate," Mater. Res. Soc. Symp. Proc. 257, 109-115 (1992).

\section{EBBINGHAUS-2000}

B. Ebbinghaus, personal communication.

\section{HART-1999}

K. P. Hart, G. R. Lumpkin, Y. Zhang, E. Loi, and S. Leung, "Durability and Natural Mineral Studies Carried out to Support Development of Waste Forms for Immobilization of Plutonium." Australian Nuclear Science and Technology Organization, Menai, Australia (1999).

HASH-1999

M. C. Hash, V. N. Zyryanov, J. K. Basco, and D. B. Chamberlain, "Fissile Materials Disposition Formulation Report", Argonne National Laboratory (1999).

\section{LUMPKIN-1991}

G. R. Lumpkin, K. L. Smith, and M. G. Blackford, "Electron Microscope Study of Synroc before and after Exposure to Aqueous Solutions," J. Mater. Res. 6, 2218-2233 (1991).

\section{OH-1991}

M. S. Oh and V. M. Oversby, "The Effect of Sample Preparation Methods on Glass Preparation," Mater. Res. Soc. Symp. Proc. 212, 123-132 (1992).

SHAW-1999

H. F. Shaw, "Determination of the Open and Closed Porosity in an Immobilized Pu Ceramic Wasteform," Lawrence Livermore National Laboratory, Livermore, CA Report UCRL-ID132605 (1998)

\section{SMITH-1997}

K. L. Smith, M. Colella, G. J. Thorogood, M. G. Blackford, G. R. Lumpkin, K. P. Hart, K. Prince, E. Loi, and A. Jostsons, "Dissolution of Synroc in Deionized Water at $150^{\circ} \mathrm{C}$," Mater. Res. Soc. Symp. Proc. 465, 349-354 (1997). 


\section{APPENDIX A. PROCEDURE FOR CLEANING NEW TEFLON ${ }^{\circledR}$ TEST VESSELS}

1. Rinse vessels, lids, and supports with fresh, high-purity DIW. High purity DIW is defined as having a resistivity of $>18 \mathrm{M} \Omega \mathrm{cm}$. Use at least three vessel volumes for each vessel at ambient temperature.

2. Fill vessels approximately $90 \%$ full with $5 \mathrm{wt} . \% \mathrm{NaOH}$ solution.

3. Tighten lids and place vessels in an oven preheated to $110 \pm 10^{\circ} \mathrm{C}$.

(*Note: In order to minimize leakage, it is suggested that the vessels be placed in secondary containers and that water be added to the secondary containers.)

4. Retighten the vessel lids after 12 to 24 hours in oven.

(*Note: If vessels have leaked, refill with DIW.)

5. After at least 5 days in oven, remove vessels and allow them to cool to room temperature.

6. Remove lids carefully and dispose of $\mathrm{NaOH}$ solution.

7. Rinse vessels and lids in fresh, high-purity DIW.

8. Repeat step 7.

9. Place vessels and lids in fresh, boiling high-purity DIW for a minimum of 1 hour.

10. Repeat steps 7 through 9 .

11. Allow vessels and lids to air-dry for a minimum of 8 hours at $90 \pm 10^{\circ} \mathrm{C}$.

12. Fill vessels about $90 \%$ full with fresh, high-purity DIW at ambient temperature.

13. Tighten lids and place vessels in oven preheated to $90 \pm 10^{\circ} \mathrm{C}$ for a minimum of 8 hours.

14. Remove vessels and allow them cool to room temperature.

15. Take an aliquot of liquid from each vessel and measure $\mathrm{pH}$.

16. If $\mathrm{pH}$ is below 5 , repeat steps 1 through 15 until $\mathrm{pH}$ is above 5 . 
17. If $\mathrm{pH}$ is above 7 , repeat steps 7 through 15 .

18. If $\mathrm{pH}$ is between 5.0 and 7.0, take a second aliquot and send for $\mathrm{F}^{-}$analysis using an ion-specific electrode (ISE).

19. If ISE $\mathrm{F}^{-}$level is $>0.5 \mathrm{ppm}(\mu \mathrm{g} / \mathrm{mL})$, repeat steps 1 through 19 .

20. If ISE $\mathrm{F}^{-}$level is $<0.5 \mathrm{ppm}(\mu \mathrm{g} / \mathrm{mL})$, a vessel is acceptable for use and should stored in a clean marked container.

\section{PROCEDURE FOR CLEANING USED TEFLON ${ }^{\circledR}$ TEST VESSELS}

1. Rinse vessels, lids, and supports with fresh high-purity water. Use at least three vessel volumes of water for each vessel.

2. Soak vessels and supports for at least 2 hours in $0.16 \mathrm{M} \mathrm{HNO}_{3}\left(1 \mathrm{wt} . \mathrm{HNO}_{3}\right.$ ) at $90 \pm 10^{\circ}$.

3. Rinse again as specified in step 1 .

4. Soak for at least1 $\mathrm{h}$ in high purity water at $90 \pm 10^{\circ} \mathrm{C}$.

5. Fill the vessels approximately $90 \%$ full with fresh high-purity water with support in place. Close the lids and hold for at least 8 hours at $90 \pm 10^{\circ} \mathrm{C}$ and then measure the $\mathrm{pH}$ and fluoride from aliquots of at least two vessels from each batch.

6. Repeat steps 3 and 4 until the $\mathrm{pH}$ is in the range of 5.0 to 7.0 and the $\mathrm{F}^{-}$is $<0.5 \mathrm{ppm}$ $(\mu \mathrm{g} / \mathrm{ml})$. If the $\mathrm{pH}$ and fluoride requirements cannot be achieved by three repetitions of steps 3 and 4 , then repeat the cleaning procedure starting at step 1 .

7. Dry vessels and lids at $90 \pm 10^{\circ} \mathrm{C}$ for a minimum of 16 hours and store inside a clean environment until used. 


\section{APPENDIX B. Hf-Ce-Ce TEST DATA}

Table B-1. Test information from three-day MCC-1 tests with the Hf-Ce-Ce ceramic. Uncertainties for the monolith measurements are estimated as about $10 \%$. (Uncertainties for the mass measurements are $<1 \%$.)

$\begin{array}{|cccccc|}\begin{array}{c}\text { Monolith } \\ \text { surface } \\ \text { finish }\end{array} & \begin{array}{c}\text { Monolith } \\ \text { diameter, }\end{array} & \begin{array}{c}\text { Monolith } \\ \text { thickness, }\end{array} & \begin{array}{c}\text { Monolith } \\ \text { surface area, }\end{array} & \begin{array}{c}\text { Leachate } \\ \text { solution mass, }\end{array} & \begin{array}{c}\text { Acid strip } \\ \text { solution mass, }\end{array} \\ 240 \mathrm{a} & 9.99 & 2.69 & 2.41 \times 10^{-4} & 17.51 & \mathrm{~g} \\ 240 \mathrm{~b} & 9.94 & 2.49 & 2.33 \times 10^{-4} & 17.51 & 17.69: \\ 240 \mathrm{c} & 10.04 & 2.7 & 2.44 \times 10^{-4} & 17.52 & 18.53 \\ 600 \mathrm{a} & 9.78 & 2.63 & 2.31 \times 10^{-4} & 17.65 & 17.71 \\ 600 \mathrm{~b} & 9.8 & 2.64 & 2.32 \times 10^{-4} & 17.46 & 18.08 \\ 600 \mathrm{c} & 9.95 & 2.57 & 2.36 \times 10^{-4} & 17.39 & 18.09\end{array}$

Table B-2. Concentrations, in ppb, in leachates and acid strip solutions from blank MCC-1 tests run in conjunction with the Hf-Ce-Ce ceramic tests. (Analytical uncertainties are about 15\%.)

\begin{tabular}{|c|c|c|c|c|c|c|c|c|c|}
\hline Test & $\mathrm{pH}$ & $\begin{array}{c}\mathrm{Ca} \\
\text { Leachate }\end{array}$ & $\begin{array}{c}\text { Ca } \\
\text { Acid strip }\end{array}$ & $\begin{array}{c}\mathrm{Ti} \\
\text { Leachate }\end{array}$ & $\begin{array}{c}\mathrm{Ti} \\
\text { Acid strip }\end{array}$ & $\begin{array}{c}\mathrm{Hf} \\
\text { Leachate }\end{array}$ & $\begin{array}{c}\mathrm{Hf} \\
\text { Acid strip }\end{array}$ & $\begin{array}{c}\text { Mo } \\
\text { Leachate }\end{array}$ & $\begin{array}{c}\text { Mo } \\
\text { Acid strip }\end{array}$ \\
\hline Blanki - A & 5.2 & 18.8 & 125 & 0.279 & 0.871 & $<0.006$ & $<0.006$ & $<0.45$ & $<0.45$ \\
\hline Blank - B & 4.8 & 37.9 & 50.8 & 0.205 & 0.355 & $<0.006$ & $<0.006$ & $<0.45$ & $<0.45$ \\
\hline Blank - C & 5.1 & 67.6 & 46.0 & 0.414 & 0.621 & $<0.006$ & $<0.006$ & $<0.45$ & $<0.45$ \\
\hline Average $^{1}$ & & 41.4 & 48.4 & 0.30 & 0.62 & 0.003 & 0.003 & 0.022 & 0.022 \\
\hline St. Dev. & & 20 & 3 & 0.1 & 0.3 & 0 & 0 & 0 & 0 \\
\hline $\begin{array}{l}\text { Background } \\
\text { to be } \\
\text { subtracted }\end{array}$ & & 41.4 & 48.4 & 0.3 & 0.62 & 0 & 0 & 0 & 0 \\
\hline$\angle O Q$ & & 65.8 & 65.8 & 0.32 & 0.32 & 0.02 & 0.02 & 0.15 & 0.15 \\
\hline LOD & & 19.7 & 19.7 & 0.096 & 0.096 & 0.006 & 0.006 & 0.045 & 0.045 \\
\hline
\end{tabular}

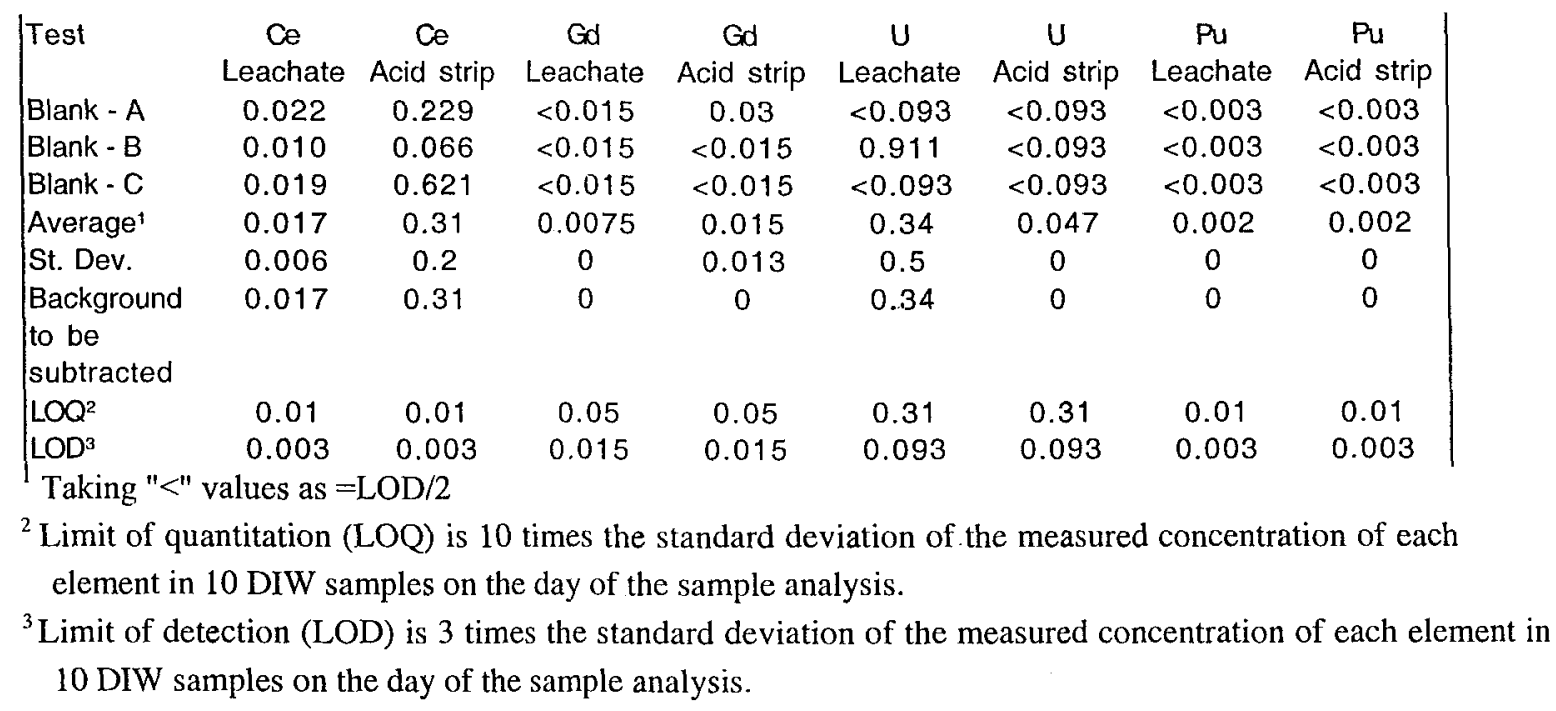


Table B-3. Total (uncorrected) concentrations, in $\mathrm{ppb}$, in leachates and acid strip solutions from three day MCC-1 tests with the Hf-Ce-Ce ceramic. (Three tests were conducted with 240-grit finish and three tests were conducted with 600 -grit finish. Analytical uncertainties are about $15 \%$.)

\begin{tabular}{|c|c|c|c|c|c|c|c|c|c|}
\hline & $\mathrm{pH}$ & $\mathrm{Ca}$ & $\mathrm{Ca}$ & $\mathrm{Ti}$ & $\mathrm{Ti}$ & $\mathrm{Hf}$ & $\mathrm{Hf}$ & Mo & Mo \\
\hline & & Leachate & Acid strip & Leachate & Acid strip & Leachate & Acid strip & Leachate & Acid strip \\
\hline $240 a$ & 5.4 & 169 & 35.0 & 1.49 & 0.426 & 0.002 & 0.004 & $<0.045$ & $<0.045$ \\
\hline $240 \mathrm{~b}$ & 5.3 & 189 & 26.0 & 0.766 & 0.284 & 0.005 & 0.006 & $<0.045$ & $<0.045$ \\
\hline $240 \mathrm{C}$ & 5.4 & 131 & 15.8 & 0.615 & 0.292 & 0.023 & 0.022 & $<0.045$ & $<0.045$ \\
\hline $600 a$ & 5.2 & 85.4 & 13.3 & 0.391 & 0.279 & 0.001 & 0.005 & $<0.045$ & $<0.045$ \\
\hline $600 \mathrm{~b}$ & 5.6 & 108 & 34.5 & 0.503 & 0.552 & 0.004 & 0.009 & $<0.045$ & $<0.045$ \\
\hline $600 \mathrm{c}$ & 5.1 & 162 & 38.9 & 0.835 & 0.442 & 0.004 & 0.015 & 0.172 & 0.21 \\
\hline LOQ & & 65.8 & 65.8 & 0.32 & 0.32 & 0.02 & 0.02 & 0.15 & 0.15 \\
\hline LOD & & 19.7 & 19.7 & 0.096 & 0.096 & 0.006 & 0.006 & 0.045 & 0.045 \\
\hline $\begin{array}{c}\text { Background } \\
\text { to be } \\
\text { subtracted }\end{array}$ & & 41.4 & 48.4 & 0.31 & 0.62 & 0 & 0 & 0 & 0 \\
\hline
\end{tabular}

\begin{tabular}{|c|cc|cc|cc|cc|}
\hline & Ce & Ce & Gd & Gd & U & $U$ & Pu & Pu \\
$240 \mathrm{a}$ & Leachate & Acid strip & Leachate & Acid strip & Leachate & Acid strip & Leachate & Acid strip \\
$240 \mathrm{~b}$ & 0.043 & 0.466 & 0.065 & 0.332 & $<0.93$ & $<0.93$ & $<0.003$ & $<0.003$ \\
$240 \mathrm{c}$ & 0.058 & 0.395 & 0.058 & 0.395 & $<0.93$ & $<0.93$ & $<0.003$ & $<0.003$ \\
$600 \mathrm{a}$ & 0.064 & 0.607 & 0.117 & 0.487 & $<0.93$ & $<0.93$ & $<0.003$ & $<0.003$ \\
$600 \mathrm{~b}$ & 0.071 & 0.897 & 0.097 & 0.530 & $<0.93$ & $<0.93$ & $<0.003$ & $<0.003$ \\
$600 \mathrm{c}$ & 0.065 & 0.456 & 0.061 & 0.297 & $<0.93$ & $<0.93$ & $<0.003$ & $<0.003$ \\
LOQ & 0.01 & 0.01 & 0.05 & 0.05 & 0.31 & 0.31 & 0.01 & 0.01 \\
LOD & 0.003 & 0.003 & 0.015 & 0.015 & 0.093 & 0.093 & 0.003 & 0.003 \\
Background & 0.017 & 0.31 & 0 & 0 & 0.34 & 0 & 0 & 0 \\
to be & & & & & & & & \\
subtracted & & & & & & & &
\end{tabular}

Table B-4. Background corrected concentrations, in ppb, in leachates and acid strip solutions from three day MCC-1 tests with the Hf-Ce-Ce ceramic. (Three tests were conducted with 240-grit finish and three tests were conducted with 600 -grit finish. Analytical uncertainties are about $21 \%$.)

\begin{tabular}{|c|cc|cc|cc|cc|}
\multicolumn{1}{c}{} & $\begin{array}{c}\mathrm{Ca} \\
\text { Leachate }\end{array}$ & Acid strip & Leachate & Acid strip & Leachate & Acid strip & Leachate & Acid strip \\
$240 \mathrm{a}$ & 127.6 & $-13.4^{\mathrm{t}}$ & 1.19 & -0.194 & 0.002 & 0.004 & $<0.045$ & $<0.045$ \\
$240 \mathrm{~b}$ & 147.6 & -22.4 & 0.466 & -0.336 & 0.005 & 0.006 & $<0.045$ & $<0.045$ \\
$240 \mathrm{c}$ & 89.6 & -32.6 & 0.315 & -0.328 & 0.023 & 0.022 & $<0.045$ & $<0.045$ \\
$600 \mathrm{a}$ & 44.0 & -35.1 & 0.091 & -0.341 & 0.001 & 0.005 & $<0.045$ & $<0.045$ \\
$600 \mathrm{~b}$ & 66.6 & -13.9 & 0.203 & -0.068 & 0.004 & 0.009 & $<0.045$ & $<0.045$ \\
$600 \mathrm{c}$ & 120.6 & -9.50 & 0.535 & -0.178 & 0.004 & 0.015 & 0.172 & 0.210
\end{tabular}

\begin{tabular}{|c|cc|cc|cc|cc|} 
& Ce & Ce & Gd & Gd & U & U & Pu & Pu \\
& Leachate & Acid strip & Leachate & Acid strip & Leachate & Acid strip & Leachate & Acid strip \\
$240 \mathrm{a}$ & 0.026 & 0.156 & 0.065 & 0.332 & $<0.93$ & $<0.93$ & $<0.003$ & $<0.003$ \\
$240 \mathrm{~b}$ & 0.019 & 0.085 & 0.058 & 0.395 & $<0.93$ & $<0.93$ & $<0.003$ & $<0.003$ \\
$240 \mathrm{c}$ & 0.041 & 0.011 & 0.080 & 0.247 & $<0.93$ & $<0.93$ & $<0.003$ & $<0.003$ \\
$600 \mathrm{a}$ & 0.047 & 0.297 & 0.117 & 0.487 & $<0.93$ & $<0.93$ & $<0.003$ & $<0.003$ \\
$600 \mathrm{~b}$ & 0.054 & 0.587 & 0.097 & 0.530 & $<0.93$ & $<0.93$ & $<0.003$ & $<0.003$ \\
$600 \mathrm{c}$ & 0.048 & 0.146 & 0.061 & 0.297 & $<0.93$ & $<0.93$ & $<0.003$ & $<0.003$
\end{tabular}

${ }^{1}$ Negative numbers are taken as zero for NL(i) calculations. 


\section{APPENDIX C. Hf-Ce-U TEST DATA}

Table C-1. Test information from MCC-1 tests with the Hf-Ce-U ceramic. (Uncertainties for the monolith measurements are estimated as about $10 \%$. Uncertainties for the mass measurements are $<1 \%$.)

\begin{tabular}{|c|c|c|c|c|c|c|}
\hline $\begin{array}{l}\text { Monolith } \\
\text { surface } \\
\text { finish }\end{array}$ & $\begin{array}{c}\text { Duration, } \\
\text { days }\end{array}$ & $\begin{array}{c}\text { Monolith } \\
\text { diameter, } \\
\mathrm{mm}\end{array}$ & $\begin{array}{c}\text { Monolith } \\
\text { thickness, } \\
\mathrm{mm}\end{array}$ & $\begin{array}{c}\text { Monolith } \\
\text { surface area, } \\
\mathrm{m}^{2}\end{array}$ & $\begin{array}{l}\text { Leachate } \\
\text { solution mass, } \\
\mathrm{g}\end{array}$ & $\begin{array}{c}\text { Acid strip } \\
\text { solution mass, } \\
g\end{array}$ \\
\hline $240 a$ & 1 & 9.92 & 1.70 & $2.08 \times 10^{-4}$ & 16.60 & 17.54 \\
\hline $240 \mathrm{~b}$ & 1 & 9.93 & 1.48 & $2.01 \times 10^{-4}$ & 16.53 & 19.60 \\
\hline $240 \mathrm{c}$ & 1 & 9.91 & 1.55 & $2.03 \times 10^{-4}$ & 16.94 & $19.32^{\circ}$ \\
\hline $600 a$ & 1 & 9.90 & 1.50 & $2.01 \times 10^{-4}$ & 16.40 & 19.64 \\
\hline $600 \mathrm{~b}$ & 1 & 9.91 & 1.51 & $2.01 \times 10^{-4}$ & 17.13 & 19.65 \\
\hline $600 \mathrm{c}$ & 1 & 9.92 & 1.72 & $2.08 \times 10^{-4}$ & 20.30 & 16.11 \\
\hline $\begin{array}{l}\text { Monolith } \\
\text { surface } \\
\text { finish }\end{array}$ & $\begin{array}{c}\text { Duration, } \\
\text { days }\end{array}$ & $\begin{array}{c}\text { Monolith } \\
\text { diameter, } \\
\mathrm{mm}\end{array}$ & $\begin{array}{c}\text { Monolith } \\
\text { thickness, } \\
\mathrm{mm}\end{array}$ & $\begin{array}{c}\text { Monolith } \\
\text { surface area, } \\
\mathrm{m}^{2}\end{array}$ & $\begin{array}{c}\text { Leachate } \\
\text { solution mass, } \\
g\end{array}$ & $\begin{array}{c}\text { Acid strip } \\
\text { solution mass, } \\
\mathrm{g}\end{array}$ \\
\hline $240 \mathrm{a}$ & 3 & 9.91 & 1.61 & $2.04 \times 10^{-4}$ & 17.65 & 18.93 \\
\hline $240 b$ & 3 & 9.92 & 1.53 & $2.02 \times 10^{-4}$ & 17.56 & 18.08 \\
\hline $240 c$ & 3 & 9.89 & 1.57 & $2.02 \times 10^{-4}$ & 21.10 & 19.36 \\
\hline $600 a$ & 3 & 9.91 & 1.66 & $2.06 \times 10^{-4}$ & 17.19 & 19.48 \\
\hline $600 \mathrm{~b}$ & 3 & 9.90 & 1.34 & $1.96 \times 10^{-4}$ & 16.96 & 19.07 \\
\hline $600 c$ & 3 & 9.91 & 1.51 & $2.01 \times 10^{-4}$ & 16.77 & 18.34 \\
\hline $\begin{array}{l}\text { Monolith } \\
\text { surface } \\
\text { finish }\end{array}$ & $\begin{array}{c}\text { Duration, } \\
\text { days }\end{array}$ & $\begin{array}{c}\text { Monolith } \\
\text { diameter, } \\
\mathrm{mm}\end{array}$ & $\begin{array}{c}\text { Monolith } \\
\text { thickness, } \\
\text { mm }\end{array}$ & $\begin{array}{c}\text { Monolith } \\
\text { surface area, } \\
\mathrm{m}^{2}\end{array}$ & $\begin{array}{c}\text { Leachate } \\
\text { solution mass, } \\
\mathrm{g}\end{array}$ & $\begin{array}{c}\text { Acid strip } \\
\text { solution mass, } \\
\mathrm{g}\end{array}$ \\
\hline $240 a$ & 5 & 9.90 & 1.45 & $1.99 \times 10^{-4}$ & 17.29 & 18.67 \\
\hline $240 b$ & 5 & 9.92 & 1.63 & $2.05 \times 10^{-4}$ & 17.32 & 19.65 \\
\hline $240 \mathrm{c}$ & 5 & 9.89 & 1.48 & $2.00 \times 10^{-4}$ & 16.91 & 20.14 \\
\hline $600 a$ & 5 & 9.91 & 1.43 & $1.99 \times 10^{-4}$ & 17.34 & 18.20 \\
\hline $600 \mathrm{~b}$ & 5 & 9.89 & 1.45 & $1.99 \times 10^{-4}$ & 17.94 & 17.76 \\
\hline $600 \mathrm{c}$ & 5 & 9.92 & 1.66 & $2.01 \times 10^{-4}$ & 17.30 & 18.67 \\
\hline $\begin{array}{l}\text { Monolith } \\
\text { surface } \\
\text { finish }\end{array}$ & $\begin{array}{c}\text { Duration, } \\
\text { days }\end{array}$ & $\begin{array}{l}\text { Monolith } \\
\text { diameter, } \\
\mathrm{mm}\end{array}$ & $\begin{array}{c}\text { Monolith } \\
\text { thickness, } \\
\text { mm }\end{array}$ & $\begin{array}{c}\text { Monolith } \\
\text { surface area, } \\
\mathrm{m}^{2}\end{array}$ & $\begin{array}{c}\text { Leachate } \\
\text { soiution mass, } \\
\mathrm{g}\end{array}$ & $\begin{array}{c}\text { Acid strip } \\
\text { solution mass, } \\
\mathrm{g}\end{array}$ \\
\hline $240 a$ & 7 & 9.89 & 1.39 & $1.97 \times 10^{-4}$ & 17.77 & 18.13 \\
\hline $240 \mathrm{~b}$ & 7 & 9.93 & 1.60 & $2.05 \times 10^{-4}$ & 17.26 & 18.32 \\
\hline $240 \mathrm{c}$ & 7 & 9.89 & 1.55 & $2.02 \times 10^{-4}$ & 17.46 & 18.04 \\
\hline $600 a$ & 7 & 9.89 & 1.70 & $2.06 \times 10^{-4}$ & 17.50 & 17.78 \\
\hline $600 \mathrm{~b}$ & 7 & 9.94 & 1.64 & $2.06 \times 10^{-4}$ & 17.14 & 18.88 \\
\hline $600 c$ & 7 & 9.93 & 1.59 & $2.04 \times 10^{-4}$ & 17.20 & 18.64 \\
\hline $\begin{array}{l}\text { Monolith } \\
\text { surface } \\
\text { finish }\end{array}$ & $\begin{array}{c}\text { Duration, } \\
\text { days }\end{array}$ & $\begin{array}{l}\text { Monolith } \\
\text { diameter, } \\
\mathrm{mm}\end{array}$ & $\begin{array}{c}\text { Monolith } \\
\text { thickness, } \\
\mathrm{mm}\end{array}$ & $\begin{array}{c}\text { Monolith } \\
\text { surface area, } \\
\mathrm{m}^{2}\end{array}$ & $\begin{array}{l}\text { Leachate } \\
\text { solution mass, } \\
\mathrm{g}\end{array}$ & $\begin{array}{c}\text { Acid strip } \\
\text { solution mass, } \\
g\end{array}$ \\
\hline $240 a$ & 14 & 9.89 & 1.71 & $2.07 \times 10^{-4}$ & 17.70 & 20.76 \\
\hline $240 b$ & 14 & 9.90 & 1.63 & $2.05 \times 10^{-4}$ & 17.45 & 19.80 \\
\hline $240 c$ & 14 & 9.92 & 1.65 & $2.06 \times 10^{-4}$ & 17.08 & 19.15 \\
\hline $600 a$ & 14 & 9.92 & 1.44 & $1.99 \times 10^{-4}$ & 18.89 & 20.86 \\
\hline $600 \mathrm{~b}$ & 14 & 9.93 & 1.59 & $2.04 \times 10^{-4}$ & 16.91 & 19.97 \\
\hline $600 \mathrm{c}$ & 14 & 9.92 & 1.60 & $2.04 \times 10^{-4}$ & 17.20 & 20.19 \\
\hline
\end{tabular}


Table C-2. Total concentrations, in ppb, in leachates and acid strip solutions from blank $\mathrm{MCC}-1$ tests conducted in conjunction with the $\mathrm{Hf}-\mathrm{Ce}-\mathrm{U}$ ceramic tests. (Analytical uncertainties are about $15 \%$.)

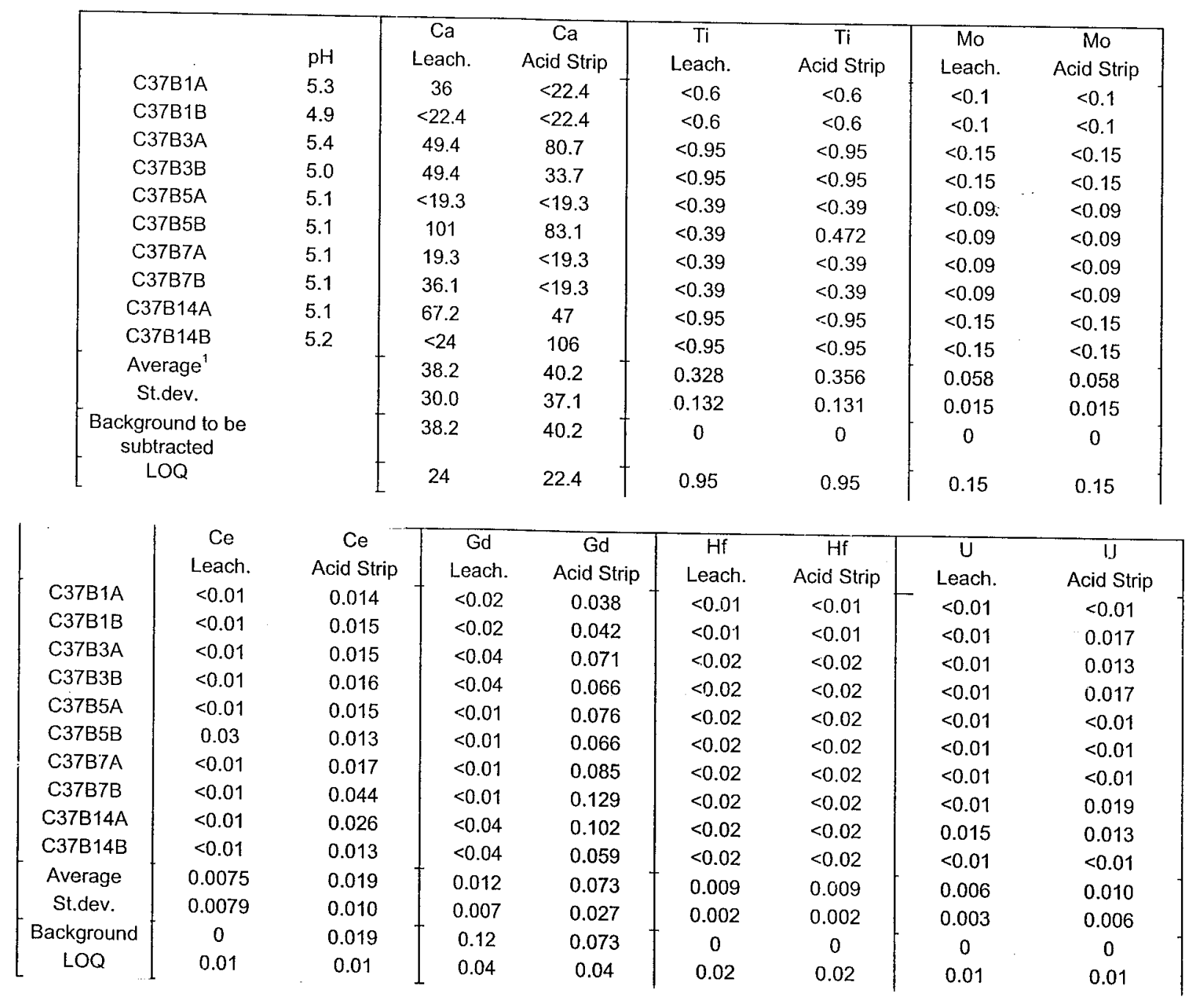


Table C-3. Total (uncorrected) concentrations, in ppb, in leachates and acid strip solutions from $\mathrm{MCC}-1$ tests with $\mathrm{Hf}-\mathrm{Ce}-\mathrm{U}$ ceramic. (Three tests were conducted with 240-grit finish and three tests were conducted with 600-grit finish. Analytical uncertainties are $15 \%$.)

\begin{tabular}{|c|c|c|c|c|c|c|c|c|c|}
\hline 1-day & $\mathrm{pH}$ & $\mathrm{Ca}$ & $\mathrm{Ca}$ & $\mathrm{Ti}$ & $\mathrm{Ti}$ & Mo & Mo & $\mathrm{Ce}$ & $\mathrm{Ce}$ \\
\hline & & Leachate & Acid strip & Leachate & Acid strip & Leachate & Acid strip & Leachate & Acid strip \\
\hline $240 a$ & 5.8 & 196 & 148 & 0.760 & 0.937 & $<0.1$ & $<0.1$ & 0.029 & 0.134 \\
\hline $240 \mathrm{~b}$ & 5.5 & 42.7 & 35.2 & $<0.6$ & $<0.6$ & 0.172 & 0.208 & 0.021 & $\because 0.087$ \\
\hline $240 \mathrm{c}$ & 5.4 & 65.4 & $<22.4$ & $<0.6$ & $<0.6$ & $<0.1$ & $<0.1$ & 0.030 & 0.128 \\
\hline $600 a$ & 5.6 & 75.0 & 76.2 & $<0.6$ & $<0.6$ & $<0.1$ & $<0.1$ & 0.034 & 0.070 \\
\hline $600 \mathrm{~b}$ & 5.3 & 113 & 48.9 & 1.12 & $<0.6$ & $<0.1$ & $<0.1$ & 0.045 & 0.098 \\
\hline $600 \mathrm{c}$ & 5.8 & 74.7 & 39.5 & $<0.6$ & $<0.6$ & $<0.1$ & $<0.1$ & $<0.01$ & 0.066 \\
\hline $\operatorname{LOQ}^{1}$ & & 22.4 & 22.4 & 0.95 & 0.95 & 0.15 & 0.15 & 0.001 & 0.001 \\
\hline Background & & 38.2 & 40.2 & 0 & 0 & 0 & 0 & 0 & 0.019 \\
\hline & $\begin{array}{c}\text { Gd } \\
\text { Leachate }\end{array}$ & $\begin{array}{c}G d \\
\text { Acid strip }\end{array}$ & $\begin{array}{c}\mathrm{Hf} \\
\text { Leachate }\end{array}$ & $\begin{array}{c}\text { Hf } \\
\text { Acid strip } \\
\end{array}$ & $\begin{array}{c}\mathrm{U} \\
\text { Leachate }\end{array}$ & $\begin{array}{c}U \\
\text { Acid strip }\end{array}$ & & & \\
\hline $240 a$ & 0.041 & 0.227 & $<0.01$ & $<0.01$ & 1.14 & 0.515 & & & \\
\hline $240 \mathrm{~b}$ & 0.041 & 0.218 & $<0.01$ & $<0.01$ & 1.44 & 0.481 & & & \\
\hline $240 c$ & 0.070 & 0.322 & $<0.01$ & $<0.01$ & 1.30 & 0.711 & & & \\
\hline $600 a$ & 0.083 & 0.266 & $<0.01$ & $<0.01$ & 1.34 & 0.495 & & & \\
\hline $600 \mathrm{~b}$ & 0.091 & 0.343 & $<0.01$ & $<0.01$ & 1.38 & 0.358 & & & \\
\hline $600 \mathrm{c}$ & $<0.02$ & 0.187 & $<0.01$ & $<0.01$ & 0.782 & 0.591 & & & \\
\hline $\mathrm{LOQ}^{1}$ & 0.04 & 0.04 & 0.02 & 0.02 & 0.01 & 0.01 & & & \\
\hline $\begin{array}{l}\text { Background } \\
\text { to be } \\
\text { subtracted }^{2}\end{array}$ & 0.12 & 0.073 & 0 & 0 & 0 & 0 & & & \\
\hline
\end{tabular}

\begin{tabular}{|c|c|c|c|c|c|c|c|c|}
\hline 3-day & $\mathrm{PH}$ & $\begin{array}{c}\text { Ca } \\
\text { Leachate }\end{array}$ & $\begin{array}{c}\text { Ca } \\
\text { Acid strip }\end{array}$ & $\begin{array}{c}\mathrm{Ti} \\
\text { Leachate }\end{array}$ & $\begin{array}{c}\mathrm{Ti} \\
\text { Acid strip }\end{array}$ & $\begin{array}{c}\text { Mo } \\
\text { Leachate }\end{array}$ & $\begin{array}{c}\text { Mo } \\
\text { Acid strip }\end{array}$ & \\
\hline $240 a$ & 5.2 & 51.4 & 60.7 & $<0.95$ & $<0.95$ & 0.019 & 0.105 & \\
\hline $240 \mathrm{~b}$ & 5.1 & 92.8 & 68.1 & $<0.95$ & $<0.95$ & 0.017 & 0.131 & \\
\hline $240 \mathrm{c}$ & 5.1 & 56.7 & 29.0 & $<0.95$ & $<0.95$ & 0.012 & 0.165 & \\
\hline $600 a$ & 5.2 & 143 & 150 & $<0.95$ & 0.999 & 0.031 & 0.086 & \\
\hline $600 \mathrm{~b}$ & 5.3 & 90.6 & 56.7 & $<0.95$ & $<0.95$ & 0.015 & 0.258 & \\
\hline $600 \mathrm{c}$ & 5.1 & 56.8 & 35.7 & $<0.95$ & $<0.95$ & 0.019 & 0.082 & \\
\hline $\mathrm{LOQ}^{1}$ & & 22.4 & 22.4 & 0.95 & 0.95 & 0.001 & 0.001 & \\
\hline $\begin{array}{c}\text { Background } \\
\text { to be } \\
\text { subtracted }^{2}\end{array}$ & & 38.2 & 40.2 & 0 & 0 & 0.0075 & 0.019 & \\
\hline & $\begin{array}{c}\mathrm{Ce} \\
\text { Leachate }\end{array}$ & $\begin{array}{c}\mathrm{Ce} \\
\text { Acid strip }\end{array}$ & $\begin{array}{c}\text { Gd } \\
\text { Leachate }\end{array}$ & $\begin{array}{c}G d \\
\text { Acid strip }\end{array}$ & $\begin{array}{c}\mathrm{Hf} \\
\text { Leachate }\end{array}$ & $\begin{array}{c}\mathrm{Hf} \\
\text { Acid strip }\end{array}$ & $\begin{array}{c}\text { U } \\
\text { Leachate }\end{array}$ & $\begin{array}{c}U \\
\text { Acid strip }\end{array}$ \\
\hline $240 a$ & 0.019 & 0.105 & 0.049 & 0.315 & $<0.02$ & $<0.02$ & 2.01 & 0.712 \\
\hline $240 \mathrm{~b}$ & 0.017 & 0.131 & $<0.04$ & 0.288 & $<0.02$ & $<0.02$ & 1.39 & 2.13 \\
\hline $240 \mathrm{c}$ & 0.012 & 0.165 & $<0.04$ & 0.353 & $<0.02$ & 0.028 & 1.59 & 1.13 \\
\hline $600 a$ & 0.031 & 0.086 & 0.074 & 0.273 & $<0.02$ & $<0.02$ & 2.09 & 0.673 \\
\hline $600 \mathrm{~b}$ & 0.015 & 0.258 & $<0.04$ & 0.201 & $<0.02$ & $<0.02$ & 1.41 & 0.822 \\
\hline $600 \mathrm{c}$ & 0.019 & 0.082 & $<0.04$ & 0.211 & $<0.02$ & $<0.02$ & 1.86 & 0.466 \\
\hline $\operatorname{LOQ}^{\prime}$ & 0.01 & 0.01 & 0.04 & 0.04 & 0.02 & 0.02 & 0.01 & 0.01 \\
\hline $\begin{array}{c}\text { Background } \\
\text { to be } \\
\text { subtracted }^{2}\end{array}$ & 0 & 0.019 & 0.12 & 0.073 & 0 & 0 & 0 & 0 \\
\hline
\end{tabular}




\begin{tabular}{|c|c|c|c|c|c|c|c|c|}
\hline & & & & & & & & \\
\hline 5-day & $\mathrm{pH}$ & $\mathrm{Ca}$ & $\mathrm{Ca}$ & $\mathrm{Ti}$ & Ti & Mo & Mo & \\
\hline & & Leachate & Acid strip & Leachate & Acid strip & Leachate & Acid strip & \\
\hline $240 a$ & 5.6 & 59.8 & 102 & $<0.39$ & 0.760 & $<0.01$ & 0.061 & \\
\hline $240 b$ & 5.2 & 79.6 & $<19.3$ & $<0.39$ & $<0.39$ & 0.026 & 0.059 & \\
\hline $240 c$ & 5.4 & 63.8 & $<19.3$ & $<0.39$ & 0.432 & $<0.01$ & 0.118 & \\
\hline $600 a$ & 5.5 & 38.2 & 26.0 & $<0.39$ & 0.419 & 0.020 & 0.052 & \\
\hline $600 \mathrm{~b}$ & 5.3 & 71.0 & 86.5 & 0.527 & 0.570 & 0.012 & 0.078 & \\
\hline $600 \mathrm{c}$ & 5.3 & 39.0 & 20.7 & $<0.39$ & $<0.39$ & 0.028 & 0.069 & \\
\hline $\mathrm{LOQ}^{\prime}$ & & 22.4 & 22.4 & 0.95 & 0.95 & 0.001 & 0.001 & \\
\hline $\begin{array}{l}\text { Background } \\
\text { to be }\end{array}$ & & 38.2 & 40.2 & 0 & 0 & 0.0075 & 0.019 & \\
\hline & $\begin{array}{c}\mathrm{Ce} \\
\text { Leachate }\end{array}$ & $\begin{array}{c}\mathrm{Ce} \\
\text { Acid strip }\end{array}$ & $\begin{array}{l}\mathrm{Gd} \\
\text { Leachate }\end{array}$ & $\begin{array}{c}G d \\
\text { Acid strin }\end{array}$ & $\mathrm{Hf}$ & Hif & U & U \\
\hline $240 a$ & $<0.01$ & $\begin{array}{l}\text { Acla strip } \\
0.061\end{array}$ & $\begin{array}{l}\text { Leachate } \\
0.020\end{array}$ & $\begin{array}{c}\text { Acid strip } \\
0.210\end{array}$ & Leachate & Acid strip & Leachate & Acid strip \\
\hline $240 \mathrm{~b}$ & 0.026 & 0.059 & 0.041 & $\begin{array}{l}0.210 \\
0.192\end{array}$ & $<0.02$ & $<0.02$ & 1.50 & 1.17 \\
\hline $240 c$ & $<0.01$ & 0.118 & 0.016 & $\begin{array}{l}0.192 \\
0.460\end{array}$ & $<0.02$ & $<0.02$ & 2.42 & 0.966 \\
\hline $600 a$ & 0.02 & 0.052 & 0.054 & & $<0.02$ & $<0.02$ & 1.41 & 2.52 \\
\hline $600 \mathrm{~b}$ & 0.012 & 0.078 & 0.035 & $\begin{array}{l}0.156 \\
0.223\end{array}$ & $<0.02$ & $<0.02$ & 1.82 & 0.882 \\
\hline $600 \mathrm{c}$ & 0.028 & 0.069 & & $\begin{array}{l}0.223 \\
0.269\end{array}$ & $<0.02$ & $<0.02$ & 1.25 & 1.81 \\
\hline$L_{O Q}{ }^{1}$ & 0.01 & 0.01 & $\begin{array}{c}0.004 \\
0.04\end{array}$ & 0.269 & $<0.02$ & $<0.02$ & 1.76 & 1.14 \\
\hline Background & 0 & 0.019 & $\begin{array}{l}0.04 \\
0.12\end{array}$ & 0.04 & 0.02 & 0.02 & 0.01 & 0.01 \\
\hline $\begin{array}{l}\text { to be } \\
\text { subtracted }\end{array}$ & & 0.019 & 0.12 & 0.073 & 0 & 0 & 0 & 0 \\
\hline
\end{tabular}

\begin{tabular}{|c|c|c|c|c|c|c|c|c|}
\hline 7-day & $\mathrm{pH}$ & $\begin{array}{c}\mathrm{Ca} \\
\text { Leachate }\end{array}$ & $\begin{array}{c}\text { Ca } \\
\text { Acid strip }\end{array}$ & $\begin{array}{c}\text { Ti } \\
\text { Leachate }\end{array}$ & $\begin{array}{c}\mathrm{Ti} \\
\text { Acid strip }\end{array}$ & $\begin{array}{c}\text { Mo } \\
\text { Leachate }\end{array}$ & $\begin{array}{c}\text { Mo } \\
\text { Acid strip }\end{array}$ & \\
\hline $240 a$ & 5.5 & 117 & 110 & 0.467 & 0.599 & 0.032 & 0.129 & \\
\hline $240 \mathrm{~b}$ & 5.3 & 76.8 & $<19.3$ & $<0.39$ & $<0.39$ & 0.034 & 0.072 & \\
\hline $240 \mathrm{c}$ & 5.2 & 86.8 & $<19.3$ & $<0.39$ & $<0.39$ & 0.013 & 0.067 & \\
\hline $600 a$ & 5.4 & 76.9 & $<19.3$ & $<0.39$ & 0.392 & $<0.01$ & 0.10 & \\
\hline $600 \mathrm{~b}$ & 5.0 & 112 & 35.0 & 0.460 & $<0.39$ & 0.020 & 0.089 & \\
\hline $600 \mathrm{c}$ & 5.2 & 126 & 54.1 & 0.493 & 0.618 & 0.026 & 0.078 & \\
\hline $\operatorname{LOQ}^{1}$ & & 22.4 & 22.4 & 0.95 & 0.95 & 0.001 & 0.001 & \\
\hline \multirow[t]{2}{*}{$\begin{array}{l}\text { Background } \\
\text { to be } \\
\text { subtracted }^{2}\end{array}$} & & 38.2 & 40.2 & 0 & 0 & 0.0075 & 0.019 & \\
\hline & $\begin{array}{c}\mathrm{Ce} \\
\text { Leachate }\end{array}$ & $\begin{array}{c}\mathrm{Ce} \\
\text { Acid strip }\end{array}$ & $\begin{array}{c}\text { Gd } \\
\text { Leachate }\end{array}$ & $\begin{array}{c}\mathrm{Gd} \\
\text { Acid strip }\end{array}$ & $\begin{array}{c}\mathrm{Hf} \\
\text { Leachate }\end{array}$ & $\begin{array}{c}\mathrm{Hf} \\
\text { Acid strip }\end{array}$ & $\begin{array}{c}U \\
\text { Leachate }\end{array}$ & $\begin{array}{c}U \\
\text { Acid strip }\end{array}$ \\
\hline $240 a$ & 0.032 & 0.129 & 0.053 & 0.439 & $<0.02$ & 0.022 & 2.04 & 1.26 \\
\hline $240 b$ & 0.034 & 0.072 & 0.066 & 0.181 & 0.021 & $<0.02$ & 1.88 & 0.779 \\
\hline $240 \mathrm{c}$ & 0.013 & 0.067 & 0.028 & 0.251 & $<0.02$ & $<0.02$ & 1.78 & 1.08 \\
\hline $600 a$ & $<0.01$ & 0.1 & 0.033 & 0.365 & $<0.02$ & 0.021 & 2.07 & 1.28 \\
\hline $600 \mathrm{~b}$ & 0.02 & 0.089 & 0.048 & 0.294 & $<0.02$ & $<0.02$ & 1.85 & 1.06 \\
\hline $600 \mathrm{c}$ & 0.026 & 0.078 & 0.276 & 0.348 & $<0.02$ & $<0.02$ & 1.79 & 0.902 \\
\hline $\mathrm{LOQ}^{\prime}$ & 0.01 & 0.01 & 0.04 & 0.04 & 0.02 & 0.02 & 0.01 & 0.01 \\
\hline $\begin{array}{l}\text { Background } \\
\text { to be } \\
\text { subtracted }\end{array}$ & 0 & 0.019 & 0.12 & 0.073 & 0 & 0 & 0 & 0 \\
\hline
\end{tabular}




\begin{tabular}{|c|c|c|c|c|c|c|c|c|}
\hline 14-day & $\mathrm{pH}$ & $\mathrm{Ca}$ & $\mathrm{Ca}$ & Ti & $\mathrm{Ti}$ & Mo & Mo & \\
\hline & & Leachate & Acid strip & Leachate & Acid strip & Leachate & Acid strip & \\
\hline $240 a$ & 5.2 & 148 & $<24$ & $<0.95$ & $<0.95$ & 0.036 & 0.086 & \\
\hline $240 \mathrm{~b}$ & 5.5 & 140 & 78.6 & $<0.95$ & $<0.95$ & 0.043 & 0.088 & \\
\hline $240 \mathrm{c}$ & 5.4 & 255 & 57.7 & 1.03 & $<0.95$ & 0.033 & 0.081 & \\
\hline $600 a$ & 5.4 & 90.0 & 64.7 & $<0.95$ & $<0.95$ & 0.152 & 0.073 & \\
\hline $600 \mathrm{~b}$ & 5.3 & 179 & 95.1 & $<0.95$ & $<0.95$ & 0.031 & 0.076 & \\
\hline $600 \mathrm{c}$ & 5.2 & 104 & 79.3 & $<0.95$ & $<0.95$ & 0.268 & 0.065 & \\
\hline $\mathrm{LOQ}^{\top}$ & & 22.4 & 22.4 & 0.95 & 0.95 & 0.001 & 0.001 & \\
\hline $\begin{array}{l}\text { Background } \\
\text { to be } \\
\text { subtracted }^{2}\end{array}$ & & 38.2 & 40.2 & 0 & 0 & 0.0075 & 0.019 & \\
\hline & $\begin{array}{c}\text { Ce } \\
\text { Leachate }\end{array}$ & $\begin{array}{c}\mathrm{Ce} \\
\text { Acid strio }\end{array}$ & Gd & $\mathrm{Gd}$ & Hff & $\mathrm{Hf}$ & U & $U$ \\
\hline $240 a$ & 0.036 & $\begin{array}{l}\text { ACIa Strip } \\
0.086\end{array}$ & $\begin{array}{c}\text { Leachate } \\
0.060\end{array}$ & Acid strip & Leachate & Acid strip & Leachate & Acid strip \\
\hline $240 \mathrm{~b}$ & 0.043 & 0.088 & $\begin{array}{l}0.060 \\
0.060\end{array}$ & 0.364 & $<0.02$ & $<.0 .02$ & 3.46 & 1.31 \\
\hline $240 c$ & 0.033 & 0.081 & $\begin{array}{l}0.060 \\
0.054\end{array}$ & 0.321 & $<0.02$ & $<0.02$ & 2.56 & 1.05 \\
\hline $600 a$ & 0.152 & 0.073 & $\begin{array}{l}0.054 \\
0.093\end{array}$ & 0.295 & $<0.02$ & $<0.02$ & 3.43 & 1.38 \\
\hline $600 b$ & 0.031 & 0.076 & $\begin{array}{l}0.093 \\
0.112\end{array}$ & 0.532 & $<0.02$ & $<0.02$ & 2.99 & 1.36 \\
\hline $600 \mathrm{c}$ & 0.268 & 0.065 & $\begin{array}{l}0.112 \\
0.110\end{array}$ & 0.498 & $<0.02$ & $<0.02$ & 3.44 & 0.949 \\
\hline $\operatorname{LOQ}^{1}$ & 0.01 & 0.01 & $\begin{array}{c}0.110 \\
0.04\end{array}$ & 0.327 & $<0.02$ & $<0.02$ & 3.89 & 0.79 \\
\hline Background & 0 & & $\begin{array}{l}0.04 \\
0.12\end{array}$ & 0.04 & 0.02 & 0.02 & 0.01 & 0.01 \\
\hline $\begin{array}{c}\text { to be } \\
\text { subtracted }^{2}\end{array}$ & & 0.019 & 0.12 & 0.073 & 0 & 0 & 0 & 0 \\
\hline
\end{tabular}

J - Limit of quantitation (LOQ) is 10 times the standard deviation of the measured concentration of each element in 10 DIW samples on the day of the sample analysis.

2 - This is the average of three blank tests. If the value is below the LOQ, then it is averaged as $\mathrm{LOQ} / 2$. If the average is $\leq \mathrm{LOQ}$, then the background is defined as zero. 
Table C-4. Background corrected concentrations, in ppb, in leachates and acid strip solutions from MCC-1 tests with the Hf-Ce-U ceramic. (Three tests were conducted with 240-grit finish and three tests were conducted with 600-grit finish. Analytical uncertainties are about 21\%.)

\begin{tabular}{|c|c|c|c|c|c|c|c|c|}
\hline \multirow[t]{2}{*}{ 1-day } & $\mathrm{Ca}$ & $\mathrm{Ca}$ & $\mathrm{Ti}$ & $\mathrm{Ti}$ & Mo & Mo & $\mathrm{Ce}$ & $\mathrm{Ce}$ \\
\hline & Leachate & Acid strip & Leachate & Acid strip & Leachate & Acid strip & Leachate & Acid strip \\
\hline $240 a$ & 158 & 115 & 0.760 & 0.937 & 0 & 0 & 0.029 & 0.115 \\
\hline $240 b$ & 4.50 & 2.30 & 0 & 0 & 0.172 & 0.208 & 0.021 & 0.068 \\
\hline $240 c$ & 27.2 & 0 & 0 & 0 & 0 & 0 & 0.030 & 0.109 \\
\hline$\overline{600 a}$ & 36.8 & 43.3 & 0 & 0 & 0 & 0 & 0.034 & 0.051 \\
\hline $600 \mathrm{~b}$ & 74.8 & 16.0 & 1.120 & 0 & 0 & 0 & 0.045 & 0.079 \\
\hline \multirow[t]{2}{*}{$600 \mathrm{c}$} & 36.5 & 6.60 & 0 & 0 & 0 & 0 & 0.010 & 0.047 \\
\hline & $\begin{array}{c}\mathrm{Gd} \\
\text { Leachate }\end{array}$ & Acid strip & {$\left[\begin{array}{c}\mathrm{Hf} \\
\text { Leachate }\end{array}\right.$} & Acid strip & $u$ & Acid strin & & \\
\hline $240 a$ & 0.041 & 0.154 & 0 & 0 & 1.14 & 0.505 & & \\
\hline $240 \mathrm{~b}$ & 0.041 & 0.145 & 0 & 0 & 1.44 & 0.471 & & \\
\hline 2400 & 0.070 & 0.249 & 0 & 0 & 1.30 & 0.701 & & \\
\hline $600 a$ & 0.083 & 0.193 & 0 & 0 & 1.34 & 0.485 & & \\
\hline $600 b$ & 0.091 & 0.270 & 0 & 0 & 1.38 & 0.348 & & \\
\hline $600 \mathrm{c}$ & 0.020 & 0.114 & 0 & 0 & 0.782 & 0.581 & & \\
\hline
\end{tabular}

\begin{tabular}{|c|c|c|c|c|c|c|c|c|}
\hline \multirow{2}{*}{ 3-day } & $\mathrm{Ca}$ & $\mathrm{Ca}$ & $\mathrm{Ti}$ & $\mathrm{Ti}$ & Mo & Mo & $\mathrm{Ce}$ & $\mathrm{Ce}$ \\
\hline & Leachate & Acid strip & Leachate & Acid strip & Leachate & Acid strip & Leachate & Acid strip \\
\hline $240 a$ & 13.2 & 27.8 & 0 & 0 & 0.156 & 0 & 0.019 & 0.086 \\
\hline $240 b$ & 54.6 & 35.2 & 0 & 0 & 0 & 0 & 0.017 & 0.112 \\
\hline $240 \mathrm{c}$ & 18.5 & 0 & 0 & 0 & 0 & 0 & 0.012 & 0.146 \\
\hline $600 a$ & 105 & 117 & 0 & 0.999 & 0.235 & 0 & 0.031 & 0.067 \\
\hline $600 \mathrm{~b}$ & 52.4 & 23.8 & 0 & 0 & 0.164 & 0 & 0.015 & 0.239 \\
\hline \multirow[t]{2}{*}{$600 \mathrm{c}$} & 18.6 & 2.80 & 0 & 0 & 0.277 & 0 & 0.019 & 0.063 \\
\hline & $\begin{array}{c}\mathrm{Gd} \\
\text { Leachate }\end{array}$ & $\begin{array}{c}\mathrm{Gd} \\
\text { Acid strip }\end{array}$ & $\begin{array}{c}\mathrm{Hf} \\
\text { Leachate }\end{array}$ & $\begin{array}{c}\mathrm{Hf} \\
\text { Acid strip }\end{array}$ & $\begin{array}{c}\mathrm{U} \\
\text { Leachate }\end{array}$ & $\begin{array}{c}U \\
\text { Acid strip }\end{array}$ & & \\
\hline $240 a$ & 0.049 & 0.242 & 0 & 0 & 2.01 & 0.702 & & \\
\hline $240 \mathrm{~b}$ & 0 & 0.215 & 0 & 0 & 1.39 & 2.12 & & \\
\hline $240 \mathrm{c}$ & 0 & 0.280 & 0 & 0.028 & 1.59 & 1.12 & & \\
\hline $600 a$ & 0.074 & 0.200 & 0 & 0 & 2.09 & 0.663 & & \\
\hline $600 b$ & 0.040 & 0.128 & 0 & 0 & 1.41 & 0.812 & & \\
\hline $600 c$ & 0.040 & 0.138 & 0 & 0 & 1.86 & 0.456 & & \\
\hline
\end{tabular}

$\left.\begin{array}{|c|cc|cc|ccc|cc|}\text { 5-day } & \text { Ca } & \text { Ca } & \text { Ti } & \text { Ti } & \text { Mo } & \text { Mo } & \text { Ce } & \text { Ce } \\ & & \text { Leachate } & \text { Acid strip } & \text { Leachate } & \text { Acid strip } & \text { Leachate } & \text { Acid strip } & \text { Leachate } & \text { Acid strip } \\ 240 \mathrm{a} & 21.6 & 69.1 & 0 & 0.760 & 0 & 0 & 0.010 & 0.042 \\ 240 \mathrm{~b} & 41.4 & 0 & 0 & 0 & 0 & 0 & 0.026 & 0.040 \\ 240 \mathrm{c} & 25.6 & 0 & 0 & 0.432 & 0.446 & 0 & 0.010 & 0.099 \\ 600 \mathrm{a} & 0.00 & 0 & 0 & 0.419 & 0 & 0 & 0.020 & 0.033 \\ 600 \mathrm{~b} & 32.8 & 53.6 & 0.527 & 0.570 & 0.226 & 0 & 0.012 & 0.059 \\ 600 \mathrm{c} & 0.800 & 0 & 0 & 0 & 0 & 0 & 0.028 & 0.050 \\ & \text { Gd } & \text { Gd } & \text { Hf } & \text { Hf } & \text { U } & \text { U } \\ & \text { Leachate } & \text { Acid strip } & \text { Leachate } & \text { Acid strip } & \text { Leachate } & \text { Acid strip } \\ \hline 240 \mathrm{a} & 0.020 & 0.137 & 0 & 0 & 1.50 & & & \\ 240 \mathrm{~b} & 0.041 & 0.119 & 0 & 0 & 2.42 & 0.956 \\ 240 \mathrm{c} & 0.016 & 0.387 & 0 & 0 & 1.41 & 2.51 \\ 600 \mathrm{a} & 0.054 & 0.083 & 0 & 0 & 1.82 & 0.872 \\ 600 \mathrm{~b} & 0.035 & 0.150 & 0 & 0 & 1.25 & 1.80 \\ 600 \mathrm{c} & 0.064 & 0.196 & 0 & 0 & 1.76 & 1.13\end{array}\right]$




$\left.\begin{array}{|c|cc|cc|ccc|cc|}\text { 7-day } & \mathrm{Ca} & \mathrm{Ca} & \mathrm{Ti} & \mathrm{Ti} & \text { Mo } & \text { Mo } & \text { Ce } & \text { Ce } \\ & & & & & & & \\ 240 \mathrm{a} & \text { Leachate } & \text { Acid strip } & \text { Leachate } & \text { Acid strip } & \text { Leachate } & \text { Acid strip } & \text { Leachate } & \text { Acid strip } \\ 240 \mathrm{~b} & 38.6 & 77.1 & 0.467 & 0.599 & 0 & 0 & 0.032 & 0.110 \\ 240 \mathrm{c} & 48.6 & 0 & 0 & 0 & 0 & 0 & 0.034 & 0.053 \\ 600 \mathrm{a} & 38.7 & 0 & 0 & 0 & 2.230 & 0 & 0.013 & 0.048 \\ 600 \mathrm{~b} & 73.8 & 2.10 & 0.460 & 0 & 0.134 & 0 & 0.020 & 0.070 \\ 600 \mathrm{c} & 87.8 & 21.2 & 0.493 & 0.618 & 2.050 & 0 & 0.026 & 0.059\end{array}\right]$

\begin{tabular}{|c|c|c|c|c|c|c|c|c|}
\hline \multirow{2}{*}{ 14-day } & $\mathrm{Ca}$ & $\mathrm{Ca}$ & $\mathrm{Ti}$ & $\mathrm{Ti}$ & Mo & Mo & $\mathrm{Ce}$ & $\mathrm{Ce}$ \\
\hline & Leachate & Acid strip & Leachate & Acid strip & Leachate & Acid strip & Leachate & Acid strip \\
\hline $240 a$ & 110 & 0 & 0 & 0 & 0.381 & 0 & 0.036 & 0.067 \\
\hline $240 b$ & 102 & 45.7 & 0 & 0 & 0 & 0 & 0.043 & 0.069 \\
\hline $240 \mathrm{c}$ & 217 & 24.8 & 1.030 & 0 & 0.241 & 0 & 0.033 & 0.062 \\
\hline $600 a$ & 51.8 & 31.8 & 0 & 0 & 0.385 & 0 & 0.152 & 0.054 \\
\hline $600 \mathrm{~b}$ & 141 & 62.2 & 0 & 0 & 0.402 & 0 & 0.031 & 0.057 \\
\hline \multirow[t]{2}{*}{$600 \mathrm{c}$} & 65.8 & 4.6 .4 & 0 & 0 & 0.390 & 0 & 0.268 & 0.046 \\
\hline & $\begin{array}{c}\text { Gd } \\
\text { Leachate }\end{array}$ & $\begin{array}{c}\text { Gd } \\
\text { Acid strip }\end{array}$ & $\begin{array}{c}\mathrm{Hf} \\
\text { !_eachate }\end{array}$ & $\begin{array}{c}\mathrm{Hf} \\
\text { Acid strip }\end{array}$ & $\begin{array}{c}\mathrm{U} \\
\text { Leachate }\end{array}$ & $\begin{array}{c}U \\
\text { Acid strip }\end{array}$ & & \\
\hline $240 a$ & 0.060 & 0.291 & 0 & 0 & 3.46 & 1.30 & & \\
\hline $240 b$ & 0.060 & 0.248 & 0 & 0 & 2.56 & 1.04 & & \\
\hline $240 \mathrm{c}$ & 0.054 & 0.222 & 0 & 0 & 3.43 & 1.37 & & \\
\hline $600 a$ & 0.093 & 0.459 & 0 & 0 & 2.99 & 1.35 & & \\
\hline $600 \mathrm{~b}$ & 0.112 & 0.425 & 0 & 0 & 3.44 & 0.939 & & \\
\hline $600 \mathrm{c}$ & 0.110 & 0.254 & 0 & 0 & 3.89 & 0.780 & & \\
\hline
\end{tabular}

